\title{
Evaluation of a Medicinal Cannabis Manufacturing Facility with an Indoor and Outdoor Grow Operation
}
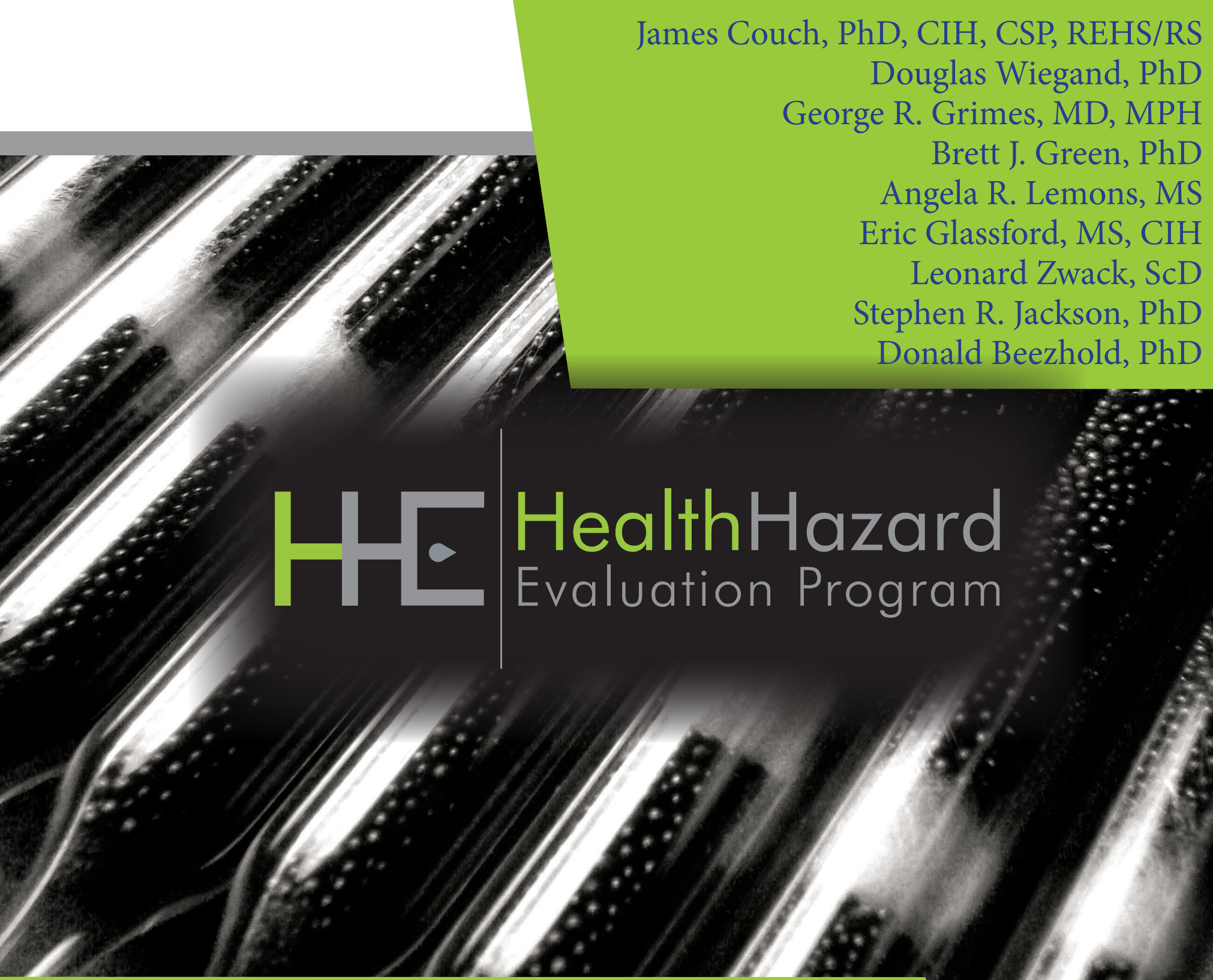

HHE Report No. 2016-0090-3317

June 2018

Revised August 2019

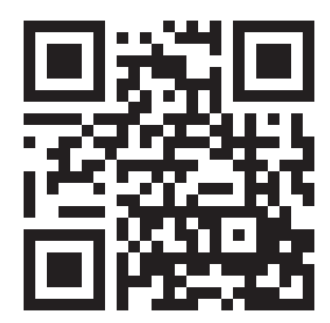

Centers for Disease Control

and Prevention

National Institute for Occupational

Safety and Health 


\section{Contents}

Highlights.

Abbreviations ...................................... iii

Introduction ............................................ 1

Methods ............................................. 2

Results and Discussion ......................... 6

Conclusions ....................................... 26

Recommendations............................. 26

Appendix A ......................................... 28

Appendix B ...................................... 31

Appendix C ..........................................35

Appendix D .........................................38

References ........................................ 41

Acknowledgements .......................... 49

The employer is required to post a copy of this report for 30 days at or near the workplace(s) of affected employees. The employer must take steps to ensure that the posted report is not altered, defaced, or covered by other material.

The cover photo is a close-up image of sorbent tubes, which are used by the HHE Program to measure airborne exposures. This photo is an artistic representation that may not be related to this Health Hazard Evaluation. Photo by NIOSH. 


\section{Highlights of this Evaluation}

The Health Hazard Evaluation Program received a request from a union representative for a medical cannabis facility with an indoor and outdoor grow operation. The representative was concerned about the potential occupational and safety hazards associated with the harvesting and processing of cannabis.

\section{What We Did}

- We visited the facility in August 2016 and April 2017.

- We observed work practices related to cultivation, harvesting, processing, and decarboxylation.

- We collected surface wipe samples for delta-9 tetrahydrocannabinol, delta-9 tetrahydrocannabinol acid, cannabidiol, and cannabinol.

- We collected air samples for volatile organic compounds including diacetyl and 2,3-pentanedione and for terpenes and oxygenated compounds.

- We collected air samples for fungal diversity analysis and endotoxins, which are products some bacteria release.

- We measured the particle concentrations in the air during a cannabis grinding operation.

- We interviewed employees about their job tasks, health and safety concerns, personal protective equipment use, injuries at work, job stress, physical working conditions, and psychosocial factors at work.

- We administered a questionnaire on health history and respiratory symptoms.

We evaluated a medical cannabis facility and detected cannabis components on surface wipes throughout the facility. Diacetyl and 2,3-pentanedione were identified in screening air samples, but later were not quantifiable in personal air samples. Observed fungal and endotoxin exposures can increase allergic and respiratory symptoms, which employees reported.

- We used spirometry to test the lung function of eight employees.

\section{What We Found}

- We found delta-9 tetrahydrocannabinol, delta-9 tetrahydrocannabinol acid, cannabidiol, and cannabinol in surface wipe samples throughout the facility.

- None of the exposures to diacetyl or 2,3-pentanedione in the air were at or above the lowest occupational exposure limit for full-shift air samples.

- Exposures to diacetyl or 2,3-pentanedione in the air during grinding were below the lowest levels the laboratory could detect.

- We detected multiple monoterpenes and sesquiterpenes throughout the facility. However, no terpene oxidation products were detected. 
- Agaricomycetes were the most common fungal class identified during both site visits; however, the amount of fungi was reduced during the April 2017 visit because of seasonal variation and decreased cannabis production.

- Full-shift endotoxin concentrations were all below the occupational exposure limit but were higher during a short grinding task.

- Airborne total particle concentration during grinding averaged 3.4 milligrams per cubic meter and ranged from 0.01 to 20.5 milligrams per cubic meter.

- Employees reported a moderate level of job stress on average. The most frequently reported source of job stress was having a heavy workload.

- Employees reported safety concerns related to working with high pressure carbon dioxide, exit doors needing a badge to unlock for egress, ergonomics, and working with large amounts of solvents.

- Employees reported concerns about having to perform tasks that are not part of their job description.

- Some employees reported allergic, irritant, and musculoskeletal symptoms.

- Breathing test results were normal for seven of eight employees tested. One result showed mild lung restriction.

- The facility had no written respiratory protection plan.

\section{What the Employer Can Do}

- Install local exhaust ventilation to reduce exposures during grinding operations.

- Move the decarboxylation process to a seldom occupied area in the facility to prevent unnecessary exposures to diacetyl and 2,3-pentanedione.

- Limit access to the areas where higher exposure tasks are occurring.

- Redesign security doors to allow emergency egress without needing a badge to exit the facility.

- Encourage employees to report new or ongoing symptoms to their personal healthcare provider and a designated health and safety representative within the workplace.

- Develop and implement a written respiratory protection program that meets the requirements of the Occupational Safety and Health Administration's respiratory protection standard.

- Talk to employees about whether workload could be better managed and how. Clearly define job roles and talk to employees how to minimize role overload. If feasible, hire more employees to reduce the workload of individuals.

\section{What Employees Can Do}

- Wear personal protective equipment according to manufacturer's instructions when required by the company.

- Report new or ongoing symptoms to your personal physician and to the designated representative within the workplace. 


\section{Abbreviations}

\begin{tabular}{|c|c|}
\hline$\Delta 9-\mathrm{THC}$ & delta-9-tetrahydrocannabinol \\
\hline$\triangle 9-\mathrm{THCA}$ & delta-9-tetrahydrocannabinol acid \\
\hline$\mu \mathrm{L}$ & Microliter \\
\hline ACGIH® & American Conference of Governmental Industrial Hygienists \\
\hline $\mathrm{CBD}$ & Cannabidiol \\
\hline $\mathrm{CBN}$ & Cannabinol \\
\hline CFR & Code of Federal Regulations \\
\hline $\mathrm{cm}^{2}$ & Square centimeters \\
\hline DECOS & Dutch Expert Committee on Occupational Safety \\
\hline DNA & Deoxyribonucleic acid \\
\hline EU & Endotoxin unit \\
\hline $\mathrm{EU} / \mathrm{m}^{3}$ & Endotoxin units per cubic meter \\
\hline $\mathrm{FEV}_{1}$ & 1-second forced expiratory volume \\
\hline $\mathrm{FEV}_{1} / \mathrm{FVC}$ & Ratio of 1 -second forced expiratory volume to forced vital capacity \\
\hline $\mathrm{FVC}$ & Forced vital capacity \\
\hline ITS & Internal transcribed spacer \\
\hline MDC & Minimum detectable concentration \\
\hline MQC & Minimum quantifiable concentration \\
\hline $\mathrm{mL}$ & Milliliter \\
\hline NA & Not applicable \\
\hline ND & Not detected \\
\hline ng & Nanograms \\
\hline $\mathrm{ng} / 100 \mathrm{~cm}^{2}$ & Nanograms per 100 square centimeters \\
\hline NHANES III & The Third National Health and Nutrition Examination Survey \\
\hline NIOSH & National Institute for Occupational Safety and Health \\
\hline OEL & Occupational exposure limit \\
\hline OSHA & Occupational Safety and Health Administration \\
\hline PCR & Polymerase chain reaction \\
\hline PEL & Permissible exposure limit \\
\hline PM & Particulate matter \\
\hline $\mathrm{ppb}$ & Parts per billion \\
\hline PPE & Personal protective equipment \\
\hline REL & Recommended exposure limit \\
\hline STEL & Short-term exposure limit \\
\hline $\mathrm{TLV} \otimes$ & Threshold limit value \\
\hline TWA & Time-weighted average \\
\hline VOC & Volatile organic compounds \\
\hline
\end{tabular}


This page left intentionally blank 


\section{Introduction}

The Health Hazard Evaluation Program received a request from the United Food and Commercial Workers International Union to evaluate potential hazards associated with harvesting and processing cannabis, commonly known as marijuana, at a medical cannabis facility. We visited the facility in August 2016 and April 2017. We evaluated chemical and microbial hazards, conducted medical interviews with employees about their health concerns, administered a medical survey including a questionnaire, and evaluated employees' lung functioning using spirometry.

\section{Background}

The facility was located in Minnesota, which has legalized cannabis for medical use. The indoor and outdoor grow facility grew Cannabis sativa and Cannabis indica. Chemical pesticides were not used on the cannabis crop. At the time of our evaluation, the facility had 13 employees.

\section{Chemical and Biological Exposures in Farming Environments}

Cannabis farming environments have numerous potential exposures of concern [CDPHE 2017]. We focused our evaluation on these potential exposures: cannabinoids (delta-9-tetrahydrocannabinol [ $\Delta 9-\mathrm{THC}]$, delta-9-tetrahydrocannabinol acid [ $\Delta 9$-THCA], cannabidiol [CBD], and cannabinol [CBN]); volatile organic compounds (VOCs) (diacetyl, 2,3-pentanedione, and terpenes [subsequent oxygenated compounds]); endotoxins; and microbial biodiversity (fungi and bacteria). $\triangle 9-\mathrm{THC}$, the psychoactive component in cannabis, is the product of $\triangle 9$-THCA (present in live and raw cannabis) decarboxylation, or the loss of a carboxyl group. Decarboxylation is achieved through aging or applying heat to cannabis. CBD and $\mathrm{CBN}$ are cannabinoids that are believed to have therapeutic properties [Abrams 2018]. VOCs are a class of chemicals that readily release into the air. Diacetyl and 2,3-pentanedione are naturally occurring VOCs that have been shown to cause airway epithelial damage in laboratory studies [NIOSH 2016].

Terpenes are a class of VOCs with a strong odor and give cannabis its characteristic smell. While terpenes themselves are generally regarded as safe, they are highly reactive with indoor oxidants such as ozone and hydroxyl radicals [Singer et al. 2006; Weschler 2000]. These reactions form highly oxidized species, including ketone and aldehyde products, many of which have shown or are suspected to cause respiratory tract effects including sensory irritation and airflow limitation [Anderson 2012; Jarvis et al. 2005].

Endotoxins are lipopolysaccharide compounds that are released by the outer cell walls of Gram-negative bacteria and can cause adverse respiratory effects such as chronic bronchitis and asthma [Castellan 1995]. Workers may also be exposed to airborne fungi that are prevalent in the air, some of which may be pathogens of a specific crop. Fungi can produce health effects by four mechanisms: infections (e.g., pulmonary aspergillosis); irritant reactions (e.g., burning, blistering skin); allergic reactions (e.g., allergic rhinitis); and toxic reactions (e.g., gastrointestinal symptoms from ingesting mycotoxins) [Trout et al. 2004]. 


\section{Process Description}

The medicinal cannabis production process begins in the clone room. Employees remove cuttings from mature donor plants in this room to create seedlings, or clones, which are new individual plants with the same characteristics as the donor plant. As the clones mature, they are moved into the adjacent grow room where they continue to mature until they are ready to move into either the indoor greenhouses (greenhouse A or B) or outdoor hoop houses (hoop house A, B, and C). Hoop houses are large, semicircular structures that are often made of fabric, which allow sunlight and air to reach plants. The number of plants in each greenhouse or hoop house depend on plant type and size. A breezeway area connecting the indoor greenhouse and the loading dock is sometimes used to house plants and perform various tasks such as preventive maintenance.

Once the plant reaches maturity, large stems, also known as colas, are removed and dried. Destemming is the process of removing dried flowers from the cola's stem. After removal, dried flowers are placed into a grinder that reduces the flowers to a smaller, more consistent size. The ground flowers are put into a decarboxylation oven (estimated oven volume of 1.5 cubic feet) and heated to $140^{\circ} \mathrm{C}$ for approximately 2 hours. The decarboxylation oven, located in the loading dock, has a vacuum pump that creates negative pressure inside the oven and exhausts outside. The resulting product is then moved to a carbon dioxide extraction system that creates oil. The extracted oil is moved to packaging and shipping for final processing.

The facility also has a quality control laboratory that monitors product quality and content. The laboratory is located next to the loading dock. Breakroom, security, and restroom facilities are located outside of the production areas.

\section{Methods}

Our objectives were to:

- Identify health hazards related to harvesting and processing cannabis among employees at this cannabis grow.

- Determine whether employees at the facility were experiencing work-related health symptoms or had health or safety concerns.

- Assess employees' perceptions of job stress and the physical and psychosocial work environment.

- Determine if employees had abnormal lung function.

Our evaluation included the following:

- Surface wipe sampling for cannabinoids including $\triangle 9$-THC, $\triangle 9$-THCA, CBD, and CBN

- Air sampling

- VOCs (VOC screening and individually sampling for diacetyl, 2,3 pentanedione, and terpenes)

- Fungal diversity

- Endotoxin 
- Assessment of airborne particle sizes and concentrations during grinding

- Confidential medical interviews with employees

- Questionnaires to evaluate respiratory symptoms

- Spirometry testing to evaluate lung function of the employees

Detailed information regarding the sampling methods and microbiological biodiversity analysis are in Appendix C.

\section{Surface Sampling for $\triangle 9-T H C$ and Other Cannabis Compounds}

In August 2016, we collected 18 surface wipe samples in areas with cannabis processing. For each sample, we noted the location and recent activities that were performed in the area. Where possible, we used a 100 -square-centimeter $\left(100 \mathrm{~cm}^{2}\right)$ template to sample a consistent surface area. Surface wipe samples were analyzed for $\Delta 9$-THC using a contract laboratory's internal method. The method used liquid chromatography and tandem mass spectrometry with a limit of detection of 40 nanograms (ng) per sample.

We collected an additional surface wipe sample directly adjacent (when possible) to the first surface wipe sample. This additional surface wipe sample was analyzed for $\triangle 9$-THC, $\triangle 9$-THCA, CBD, and CBN using a modified method (cannabinoid method) [Ambach et al. 2014]. The method used high performance liquid chromatography with diode-array detection with a limit of detection of 2 micrograms per sample for each cannabis component.

\section{Air Sampling for VOCs}

In August 2016, we collected area, task-based, and instantaneous air samples using evacuated canisters. Evacuated canister sampling consisted of a 450 milliliter $(\mathrm{mL})$ evacuated canister equipped with a restricted flow controller (15-minute or 6-hour duration) or an instantaneous flow controller that was designed for a short sampling duration ( $<30$ seconds). Area samples (approximately 6 hours) were collected as close to the source of interest as possible. We took task-based canister samples (approximately 15-minute duration) in the employees' breathing zone as they performed their work task to replicate exposure. Instantaneous canister samples ( $<30$ seconds) were taken to determine possible peak exposures during specific tasks or at a source. The canister air samples were analyzed using modifications to a previously published gas chromatograph/mass spectrometer method that allowed analysis of diacetyl, 2,3-pentanedione, and 2,3-hexanedione in addition to 17 other VOCs [LeBouf et al. 2012]. Area samples to identify terpenes and ozone reaction products, collected alongside the canisters, were analyzed using a previously published derivatization technique [Jackson et al. 2016]. An Aeroqual Series 500 portable air monitor with an ozone sensor was used to periodically record ozone concentration throughout the facility. Detailed sample method information is available in Appendix C.

Because diacetyl and 2,3-pentanedione were detected in the canister samples we collected in August 2016, we returned in April 2017 and collected full-shift personal and area air samples 
using two different sampling methods to measure employee's exposures to diacetyl and 2,3-pentanedione. We also collected task-based personal air samples during grinding and decarboxylation. The first method is an Occupational Safety and Health Administration (OSHA) Method (1013/1016), which uses silica gel sorbent tubes [OSHA 2008, 2010]. This is the standard method for measuring diacetyl and 2,3-pentanedione. To increase the ability to measure these chemicals at lower concentrations, the method was modified to use a gas chromatograph/ mass spectrometer operated in selected ion monitoring mode instead of a gas chromatograph/ mass spectrometer with a flame ionization detector [LeBouf and Simmons 2017]. We collected 13 full-shift personal and 8 area air samples with pumps calibrated to a flow rate of 50 cubic centimeters per minute, over 2 days. We also collected 8 personal task-based air samples during grinding and decarboxylation tasks using pumps operating at a flow rate of 200 cubic centimeters per minute (increased flow rate due to shorter sampling times for tasks).

The second method used evacuated canisters as described for the August 2016 visit. We collected the canister samples alongside the OSHA method samples. We collected 14 fullshift personal and 8 area air samples and 8 task-based personal air samples. Full-shift samples were collected using flow controllers set for 8-12 hours; task-based samples were collected using flow controllers set for 15-minute samples.

In April 2017, we collected 10 area air samples using thermal desorption tubes to identify volatile contaminants at the facility. These tubes were analyzed by National Institute for Occupational Safety and Health (NIOSH) Method 2549 [NIOSH 2018].

\section{Air Sampling for Microbial Biodiversity}

In August 2016 and April 2017, we collected 12 full-shift breathing zone and 25 area air samples using a NIOSH two-stage bioaerosol sampler to assess microbial exposures that may arise during the handling of plant material. In August 2016, we collected full-shift personal breathing zone air samples from four employees over 2 days ( 8 samples in all). We collected 11 area samples in the following locations: vegetation room (2), clone room (2), greenhouse 1 (1), greenhouse 2 (1), hoop house C (2), hoop house B (1), loading dock (1), and the breakroom (1). Hoop house samples were collected in the outdoor grow while the greenhouse samples were collected in the indoor grow.

Complete details of the sampling and microbial biodiversity analysis are in Appendix C. In brief, we processed the deoxyribonucleic acid (DNA) in the samples and used it to identify varieties of fungi by comparing our results to the National Center for Biotechnology Information database. The results are reported in terms of relative abundance, which is the percentage of each type out of the total in the sample.

\section{Endotoxin}

In August 2016, we collected endotoxin breathing zone air samples on four employees over 2 days ( 8 samples in all) during their entire work shift. One breathing zone task sample was collected during the decarboxylation task on day 2. Each sample was collected with threepiece 37-millimeter closed-face cassettes, preloaded with 0.45-micrometer-pore-size endotoxinfree polycarbonate filters. Samples were collected at an airflow rate of 2 liters per minute. 
Samples were analyzed for endotoxin content with the kinetic-chromogenic procedure using the limulus amebocyte lysate assay [Cambrex 2005]. For these analyses, one endotoxin unit (EU) was equivalent to $0.053 \mathrm{ng}$ of endotoxin. The limit of detection was $0.50 \mathrm{EU}$ per sample. We collected the 12 area samples in the same location as the microbial biodiversity samples. Endotoxin samples were only collected during the August 2016 site visit.

\section{Particle Concentrations During Grinding}

In August 2016, we measured the particle concentration during a grinding task using a TSI DustTrak $^{\mathrm{TM}}$ DRX 8533 Aerosol Monitor. We measured particle concentrations in different size groups: particulate matter (PM) smaller than 1 micrometer $(\mu \mathrm{m})(\mathrm{PM} 1), \mathrm{PM}$ smaller than $2.5 \mu \mathrm{m}$ (PM2.5), respirable (less than $4 \mu \mathrm{m})$, PM smaller than $10 \mu \mathrm{m}$ (PM10), and total PM (less than $100 \mu \mathrm{m}$ ).

\section{Medical Interviews}

We conducted confidential medical interviews in August 2016 to discuss potential health and safety concerns during cannabis processing. The interviews were broad in scope to identify areas in need of further evaluation during a subsequent site visit. The interviews included scaled, yes/no, and open-ended questions to assess job tasks, health and safety concerns, personal protective equipment (PPE) use, injuries at work, job stress, working conditions, and psychosocial factors at work. The interview form is in Appendix B.

\section{Questionnaire}

During the April 2017 site visit, we used an interviewer-administered questionnaire to obtain a work history with the current company and any other cannabis facilities, assessed cigarette smoking history, and asked about current respiratory health symptoms and diagnoses. Questions on respiratory health were derived from five standardized questionnaires: the European Community Respiratory Health Survey [Burney et al. 1994; ECRHS 2014], the American Thoracic Society adult respiratory questionnaire (ATS-DLD-78) [Ferris 1978], the International Union Against Tuberculosis and Lung Disease [Burney and Chinn 1987; Burney et al. 1989], and the Third National Health and Nutrition Examination Survey (NHANES III) [Centers for Disease Control and Prevention 1996] and NHANES 2007-2012 questionnaires [NCHS 2015] and were supplemented with additional questions.

\section{Spirometry}

Spirometry is used to determine how an individual moves air in and out of their lungs. The results are compared to "normal" expected values from members of the general population. The test includes measurements of the total amount of air that an individual can forcefully blow out after a deep breath, known as forced vital capacity (FVC). The test also measures the amount of air that an individual blows out in the first second of exhalation, known as the 1 -second forced expiratory volume $\left(\mathrm{FEV}_{1}\right)$. These measures can be compared against one another in a ratio $\left(\mathrm{FEV}_{1}\right.$ to $\left.\mathrm{FVC}\right)$, which provides information about whether an individual's results are normal, obstructive (meaning air is obstructed from moving in and 
out of the lungs), or restrictive (meaning the lung cannot expand, so only low volumes can enter and exit the lung). In addition to spirometry, we also obtained the body mass index for employees, as an elevated body mass index (defined as a body mass index greater than 25) can result in a restrictive pattern on spirometry, despite the absence of lung disease. We measured height with a stadiometer and weight with a calibrated scale.

We used a flow spirometer to measure exhaled air volumes and flow rate. We used the American Thoracic Society criteria for acceptability and repeatability [Miller et al. 2010]. We used equations for predicted values and lower limits of normal derived from NHANES III data to define abnormal spirometry [Hankinson et al. 1999]. NHANES III, a nationwide study completed from 1988-1994, provides researchers standard breathing test values to compare against. We defined obstruction as an $\mathrm{FEV}_{1}$ below the lower limit of normal and a ratio of $\mathrm{FEV}_{1} / \mathrm{FVC}$ below the lower limit of normal as well; restriction was defined as an $\mathrm{FVC}$ below the lower limit of normal and a normal $\mathrm{FEV}_{1} / \mathrm{FVC}$ ratio. A mixed obstruction and restriction pattern was defined as having as an $\mathrm{FEV}_{1}, \mathrm{FVC}$, and $\mathrm{FEV}_{1} / \mathrm{FVC}$ ratio all below the lower limits of normal. The severity of abnormalities was further categorized based on the degree of the $\mathrm{FEV}_{1}$ below the lower limit of normal and was placed in one of the four categories: mild, moderate, severe, and very severe [Pelligrino et al. 2005a,b].

\section{Results and Discussion}

\section{Surface Sampling for $\triangle 9$-THC and Other Cannabinoids}

Surface wipe samples were collected via two methods. One method reported $\triangle 9$-THC only, and the second method reported four cannabinoids ( $\triangle 9$-THC, $\triangle 9-\mathrm{THCA}, \mathrm{CBD}$, and CBN).

For the $\triangle 9$-THC only method, 15 out of 18 surface wipe samples had detectable levels of $\triangle 9$-THC. The surface wipe results ranged from none detected to 53,000 nanograms per 100 square centimeters $\left(\mathrm{ng} / 100 \mathrm{~cm}^{2}\right)$. The three surface wipe samples with no detectable $\Delta 9-\mathrm{THC}$ were collected in the breezeway area.

For the cannabinoid method, results varied throughout the facility. $\Delta 9$-THCA concentrations were higher than $\triangle 9$-THC concentrations in all samples except for one sample collected near the decarboxylation oven. A previous NIOSH health hazard evaluation report suggested that in raw cannabis workplaces, $\triangle 9$-THCA concentrations would be present in higher concentrations than $\triangle 9$-THC concentrations because the $\triangle 9$-THCA would not have been decarboxylated through heat or aging [NIOSH 2017]. At this workplace, the decarboxylation oven was an area were $\triangle 9$-THCA readily converted into $\triangle 9$-THC.

Results for both surface wipe sample methods are given in Appendix A, Table A1. Although the samples were collected side-by-side when possible, because of presumed unequal distribution of cannabinoids across surfaces, even when directly adjacent, we cannot directly compare results. 


\section{Air Sampling for Volatile Organic Compounds}

\section{Canister Volatile Organic Compound Screening}

During the 2016 site visit, we collected 10 evacuated canister area air samples over 2 days for 6 to 8 hours per sample. The evacuated canister method is a screening tool used to identify potential VOCs in the air. During analysis, we identified diacetyl in all area canister samples and 2,3-pentanedione in three out of the 10 canister samples. Table 1 presents the area sample results for diacetyl and 2,3-pentanedione and corresponding minimum detectable concentrations (MDC) and minimum quantifiable concentrations (MQC). All canister diacetyl results were below 5 parts per billion (ppb) except for one sample collected in the loading dock area on day 2 (11.6 ppb). For 2,3-pentanedione, the same loading dock sample was also higher on day $2(9.3 \mathrm{ppb})$ than on day 1 (not detected [ND]). The loading dock samples were collected near the decarboxylation oven, which was only used during day 2 of our visit. It is likely that the higher diacetyl and 2,3-pentanedione concentrations at the loading dock on day 2 were due to the decarboxylation oven process.

Table 1. Area canister air sampling results in parts per billion in August 2016*

\begin{tabular}{lcc}
\hline Sample location & Diacetyl & 2,3-pentanedione \\
\hline Day 1 & & ND \\
Greenhouse A & {$[1.6]$} & ND \\
Greenhouse B & 3.0 & ND \\
Loading dock & {$[1.9]$} & ND \\
Outside grow & {$[2.1]$} & ND \\
Vegetation room & 3.3 & \\
Day 2 & & {$[2.8]$} \\
Greenhouse A & 4.7 & ND \\
Greenhouse B & 3.7 & 9.3 \\
Loading dock & 12 & ND \\
Outside grow & {$[1.6]$} & {$[1.3]$} \\
Vegetation room & 2.7 & \\
\hline ND = None detected & \\
*Sample duration: 6-8 hours \\
Values in brackets are between the MDC and MQC. \\
The diacetyl MDC and MQC ranges were 0.7-2.3 ppb. \\
The 2,3-pentanedione MDC and MQC ranges were \\
1.3-4.4 ppb.
\end{tabular}


All task-based or instantaneous canister area samples, shown in Table 2, had detectable concentrations of diacetyl, but 2,3-pentanedione concentrations ranged from ND to $5.1 \mathrm{ppb}$. The highest diacetyl concentration ( $23 \mathrm{ppb}$ ) was an instantaneous sample taken immediately after the decarboxylation oven door was opened and the oven was full of dried material. The second oven door open sample concentration (1.2 ppb) was a 15-minute sample taken throughout the entire process of emptying the oven contents.

Table 2. Task-based canister air sampling results in parts per billion

\begin{tabular}{lcccc}
\hline Sample location & Task & Sample type & Diacetyl & 2,3-pentanedione \\
\hline Decarboxylation & Open oven & Instantaneous & 23 & {$[4.4]$} \\
oven & Open oven & 15 minute & {$[1.2]$} & ND \\
& Emptying oven & 15 minute & {$[1.9]$} & ND \\
& Oven exhaust & 15 minute & 6.7 & {$[1.7]$} \\
Weighing plant material & 15 minute & 6.4 & ND \\
Grinding & Grinding 1 & 15 minute & {$[0.7]$} & ND \\
& Grinding 2 & 15 minute & {$[1.5]$} & ND \\
Greenhouse A & Moving plants & 15 minute & {$[3.0]$} & ND \\
Vegetation room & Moving plants & 15 minute & 5.8 & 5.1 \\
\hline
\end{tabular}

Values in brackets are between the MDC and MQC. The diacetyl MDC and MQC ranges were 0.7-2.3 ppb. The 2,3-pentanedione MDC and MQC ranges were 1.3-4.4 ppb.

The area samples also identified other VOCs in the air, but their concentrations were well below their respective applicable occupational exposure limit (OEL). VOCs identified in concentrations greater than $1 \mathrm{ppb}$ were acetone (7.3-40 ppb), benzene (2.2 ppb), acetonitrile (3.7-5.3 ppb), d-limonene (2.5-9.3 ppb), ethanol (19-6,600 ppb), ethylbenzene (0.8-1.9 ppb), isopropyl alcohol (4.7-33 ppb), m,p-xylene (0.7-2.4 ppb), methyl methacrylate (1.5 ppb), and toluene $(0.7-1.1 \mathrm{ppb})$.

During the April 2017 site visit, we collected thermal desorption tube samples as a VOC screening tool. The most common chemical identified and with the largest peak was ethanol. Other VOCs identified most frequently and with the largest peaks were propane, acetaldehyde, terpenes (including beta-pinene and limonene), and decamethylcylcopentasiloxane. Diacetyl and 2,3-pentanedione were not present on these tubes.

The evacuated canister samples were also used as a screening tool for VOCs. These VOCs identified by these samples were all well below their respective applicable OELs. The VOCs identified in concentrations greater than their respective MQC were acetaldehyde (25-48 ppb), acetone (13-920 ppb), acetonitrile (49-78 ppb), benzene (22 ppb), d-limonene (9.5-1,400 ppb), ethanol (92-91,000 ppb), n-hexane (4.4-15 ppb), isopropyl alcohol (17-1,100 ppb), alpha-pinene (4.6-780 ppb), and toluene (5.7 ppb). 


\section{Diacetyl and 2,3-pentanedione (OSHA Method)}

Because the evacuated canister method is not a fully validated method, we returned to the facility in April 2017 to sample specifically for diacetyl and 2,3-pentanedione using a validated method. Table 3 presents the results for personal air monitoring for diacetyl and 2,3-pentanedione. Over 2 days, none of the personal air samples were above any 8-hour time-weighted average (TWA) OELs and most samples had nondetectable levels of these chemicals. On day 2, diacetyl was measured in all three cultivator samples between the MDC and MQC. All three employees performed the same job tasks. Two of the three cultivators only had detectable diacetyl concentrations during the second half of their shift. The cultivator with the highest result of $0.51 \mathrm{ppb}$ had detectable diacetyl concentrations during the first and second half of the work shift. On day 1, three security staff members were sampled; however, the sampling pump failed for one of the security staff and no sample was collected. We also collected area task-based air samples during a grinding operation and during loading and unloading of the decarboxylation oven. None of these samples had detectable diacetyl concentrations. These results are in Table 3 along with the NIOSH recommended exposure limit (REL) and the American Conference of Governmental Industrial Hygienists $(A C G I H ®)$ threshold limit value (TLV®) for reference.

Table 3. Full-shift personal air sampling results in parts per billion, OSHA method in April 2017

\begin{tabular}{cccc}
\hline Job title & $\begin{array}{c}\text { Sample duration } \\
\text { (minutes) }\end{array}$ & Diacetyl & 2,3-pentanedione \\
\hline Day 1 & 348 & ND & ND \\
Cultivator & 400 & ND & ND \\
Cultivator & 524 & ND & ND \\
Lab staff & 374 & ND & ND \\
Lab staff & 191 & ND & ND \\
Security* & 378 & ND & ND \\
Security & & & ND \\
Day 2 & 383 & {$[0.51] \dagger$} & ND \\
Cultivator & 378 & {$[0.36]$} & ND \\
Cultivator & 376 & {$[0.37]$} & ND \\
Cultivator & 527 & ND & ND \\
Lab staff & 380 & ND & ND \\
Lab staff & 183 & ND & ND \\
Security* & 376 & ND & 9.3 \\
Security & & 5.0 & - \\
\hline NIOSH REL & & 10 & \\
ACGIH TLV & & &
\end{tabular}

*Sampled only partial shift of worker

†Values in brackets are between the MDC and MQC. This means there is more uncertainty associated with the value. The MDC and MQC ranges were $0.29-1.07 \mathrm{ppb}$ for diacetyl. 
We also collected eight area air samples throughout the facility over 2 days. These results are in Table 4. We only detected diacetyl in the area sample collected in the afternoon on day 1 near the decarboxylation oven. No other area samples had detectable levels of diacetyl or 2,3-pentanedione.

Table 4. Full-shift area air samples in parts per billion, OSHA method in April 2017

\begin{tabular}{lccc}
\hline Area location & $\begin{array}{c}\text { Sample duration } \\
\text { (minutes) }\end{array}$ & Diacetyl & 2,3-pentanedione \\
\hline Day 1 & 345 & $\mathrm{ND}$ & $\mathrm{ND}$ \\
Grinding room & 298 & $\mathrm{ND}$ & $\mathrm{ND}$ \\
Breezeway 1 & 338 & $\mathrm{ND}$ & $\mathrm{ND}$ \\
Breezeway 2 & 550 & {$[0.26]^{*} \dagger$} & $\mathrm{ND}$ \\
Decarboxylation oven & & & \\
Day 2 & 483 & $\mathrm{ND}$ & $\mathrm{ND}$ \\
Packaging & 373 & $\mathrm{ND}$ & $\mathrm{ND}$ \\
Breezeway 1 & 375 & $\mathrm{ND}$ & $\mathrm{ND}$ \\
Breezeway 2 & 561 & $\mathrm{ND}$ & $\mathrm{ND}$ \\
Decarboxylation oven & &
\end{tabular}

*Values in brackets are between the MDC and MQC. This means there is more uncertainty associated with the value. The MDC and MQC ranges were $0.30-1.03 \mathrm{ppb}$ for diacetyl.

†Only the sample collected in the afternoon had detectable concentration.

\section{Diacetyl and 2,3-pentanedione (Canister Method)}

Personal full-shift air sampling results for diacetyl and 2,3-pentanedione using evacuated canisters are shown in Table 5. Evacuated canister samples were collected side-by-side with OSHA method silica gel samples reported previously (Table 3). We detected no diacetyl in any of the personal air samples using the canister method. On day 2, we detected 2,3-pentanedione at concentrations between the MDC and MQC in personal air samples from the security guards. Both guards performed similar tasks. They were primarily stationed inside of a room near the entrance to the building, but would also make routine inspections of different locations inside of the facility throughout the day. Both results were below the lowest OELs for 2,3-pentanedione. 
Table 5. Full-shift personal air sampling results in parts per billion, canister method in April 2017

\begin{tabular}{cccc}
\hline Job title & $\begin{array}{c}\text { Sample duration } \\
\text { (minutes) }\end{array}$ & Diacetyl & 2,3-pentanedione \\
\hline Day 1 & 398 & ND & ND \\
Cultivator & 443 & ND & ND \\
Cultivator & 542 & ND & ND \\
Lab staff & 447 & ND & ND \\
Lab staff & 264 & ND & ND \\
Security* & 156 & ND & ND \\
Security* & 410 & ND & ND \\
Security & & & \\
Day 2 & 432 & ND & ND \\
Cultivator & 457 & ND & ND \\
Cultivator & 417 & ND & ND \\
Cultivator & 525 & ND & ND \\
Lab staff & 378 & ND & ND \\
Lab staff & 264 & ND & {$[4.2] \dagger$} \\
Security* & 433 & ND & {$[2.4]$} \\
Security & & 5.0 & 9.3 \\
\hline NIOSH REL & & 10 & - \\
ACGIH TLV & & &
\end{tabular}

*Sampled only partial shift of worker

†Values in brackets are between the MDC and MQC. This means there is more uncertainty associated with the value. The MDC and MQC ranges were 2.2-10 ppb for 2,3-pentanedione.

We also collected eight full-shift area air samples using the canister method throughout the facility over 2 days. These samples were collected side-by-side with the OSHA method silica gel samples. We did not detect diacetyl $(\mathrm{MDC}=1.2 \mathrm{ppb})$ or 2,3-pentanedione $(\mathrm{MDC}=2.2 \mathrm{ppb})$ in any canister area air samples.

Task-based personal air samples during grinding and decarboxylation tasks are shown in Table 6. Short duration exposures varied during decarboxylation from none detected to $21 \mathrm{ppb}$. These exposures were higher for diacetyl and 2,3-pentanedione on the second day of sampling although no changes in work practices or amount of product processed were noted. The personal task-based sample collected at the same time and location with the OSHA methodology did not have a detectable amount of diacetyl on it. Exposures to diacetyl or 2,3-pentandione in the air during grinding were below the lowest levels the laboratory could detect. 
Table 6. Task-based personal air sampling results in parts per billion, evacuated canister method in April 2017

\begin{tabular}{lccc}
\hline Job title & $\begin{array}{c}\text { Sample duration } \\
\text { (minutes) }\end{array}$ & Diacetyl & 2,3-pentanedione \\
\hline Day 1 & 7 & ND & ND \\
Decarboxylation* task 1 & 4 & {$[2.4] \dagger$} & ND \\
Decarboxylation task 2 & 4 & {$[3.5]$} & ND \\
Decarboxylation task 3 & 9 & ND & ND \\
Grinding task 1 & 15 & ND & ND \\
Grinding task 2 & & & \\
Day 2 & 4 & ND & ND \\
Decarboxylation task 1 & 4 & {$[2.3]$} & {$[3.9]$} \\
Decarboxylation task 2 & 5 & 21 & 25 \\
Decarboxylation task 3 & & 25 & 30 \\
\hline NIOSH REL-STEL & & 20 & - \\
ACGIH TLV-STEL & & & \\
\hline
\end{tabular}

STEL = Short-term exposure limit

*The decarboxylation task involved loading and unloading the oven to heat cannabis.

†Values in brackets are between the MDC and MQC. This means there is more uncertainty associated with the value. The MDC and MQC ranges were 1.7-7.6 ppb for diacetyl, and 3.3-11 ppb for 2,3-pentanedione.

Currently, the evacuated canister method is partially validated [LeBouf et al. 2012] and not considered the standard method. During the second site visit, we sampled for diacetyl and 2,3-pentanedione using the standard, validated method (OSHA method) and the evacuated canister method (partially validated). We collected the samples side-by-side to compare their results directly. The concentrations the evacuated canister method measured tended to be higher than the corresponding OSHA silica gel tube method. Because the OSHA method is the standard, validated method, we used the results from these samples to form our recommendations.

None of the full-shift personal diacetyl or 2,3-pentanedione air sampling results, regardless of method, were above applicable OELs. In addition, none of the full-shift exposures to diacetyl were above the NIOSH action level of 2.6 ppb [NIOSH 2016]. Full-shift personal air sampling results on the second day of sampling showed detectable, but not quantifiable, levels of diacetyl on all three cultivators, via the OSHA method. No other full-shift personal samples measured detectable levels of diacetyl or 2,3-pentanedione.

\section{Terpenes and Ozone Reaction Products}

During the first site visit, 15 monoterpenes (a class of terpenes) and 6 sesquiterpenes (another class of terpenes) were identified in the evacuated canister air samples (Appendix A, Table A2). Ozone levels were periodically recorded throughout the facility with values ranging from 10 to $32 \mathrm{ppb}$ (Appendix A, Table A3). However, no oxidized reaction products were detected (MDC $\leq 2 \mathrm{ppb}$ ). Because of the facility's rural setting, it is unlikely that ambient ozone levels will consistently reach levels high enough to react with terpenes to generate high levels of oxidized reaction products. 


\section{Air Sampling for Microbiological Biodiversity Analysis}

\section{First Site Visit, August 2016}

We identified 569 internal transcribed spacer (ITS) sequences in the general area and personal air samples. These sequences were clustered into 137 taxonomic units derived from fungi (131) and plants (6). Figures 1A-1D show the relative abundance by phylum (1A), class (1B), class according to sampling location (1C), and most common taxa (1D). The relative abundance reported in each figure is the percentage of sequences of each fungal taxonomic group compared to the total number of fungal sequences. The predominant phyla identified in the general area and personal air samples included the Basidiomycota (56\%) and Ascomycota (31\%) (Figure 1A). Plants were also detected (13\%) due to amplification of plant DNA that has been previously reported to overlap with the fungal DNA region that was sequenced [Gardes and Bruns 1993]. The plant sequences were primarily derived from Cannabis sativa.

Figure 1B depicts the relative abundance of individual fungal classes. Fungal classes with over $20 \%$ relative abundance included the Agaricomycetes (30\%), Dothideomycetes (26\%), and the Wallemiomycetes (22\%) (Figure 1B). Some differences were observed in the relative abundance of fungi observed among general area and personal air samples. Fungal sequences placed in the Wallemiomycetes, comprised 38\% of sequences in personal air samples and only $7 \%$ in general area samples (Figure 1C). In contrast, the Agaricomycetes comprised $42 \%$ of fungal sequences in general area samples and only $13 \%$ of sequences in personal air samples. Sequences placed in the Dothideomycetes as well as plants were comparable between general area and personal air samples (Figure 1C).

Analysis of the individual species is shown in Figure 1D. The 10 most abundant sequences identified in the general area and personal samples accounted for $68 \%$ of all first site visit sequences. The fungal genus Wallemia spp. was the most prevalent $(22 \%)$ followed by Epiccoccum nigrum (8\%), Ganoderma applanatum (7.4\%), Cladosporium cladosporioides (7\%), and Cladosporium sphaerospermum (5.2\%) (Figure 1D).

The sequencing results derived from the first site visit in August 2016 reveal a spectrum of fungi commonly detected in environmental samples [Green et al. 2016; Pitkäranta et al. 2011; Rittenour et al. 2014; Yamamoto et al. 2014]. The Agaricomycetes were the most frequently reported fungal sequences in general area samples. This Basidiomycota class is one of the largest groups of fungi, accounting for one fifth of all species, and is commonly associated with the breakdown of wood [Hibbett et al. 2014]. A recent analysis of an outdoor organic cannabis production facility by NIOSH revealed a similar predominance of this fungal class in outdoor and general area samples [NIOSH 2017]. Occupational exposure to spores derived from the Agaricomycetes has been associated with hypersensitivity pneumonitis in mushroom production facilities [Ampere et al. 2012; Bekci et al. 2014; Hodgson and Flannigan 2016]. The Dothideomycetes was also a prominent fungal group in general area and personal air samples during the first site visit and included species that are usually detected in the air especially during late summer months [Rittenour et al. 2014]. Personal air samples primarily consisted of sequences placed in the class Wallemiomycetes and were represented by the genus Wallemia. These data vary from a recent analysis of an outdoor 
organic cannabis production facility that showed personal samples consisted of the $C$. sativa pathogenic species, Botrytis cinerea [NIOSH 2017]. These results suggest that Wallemia was either growing on processed cannabis or was present in the general vicinity of the worker. Wallemia is a xerophilic species and is commonly identified in damp indoor [Morey et al. 2001] and agricultural environments [Lappalainen et al. 1998]. This genus is also a potential source of adverse respiratory health effects, such as hypersensitivity pneumonitis [Lappalainen et al. 1998].

A

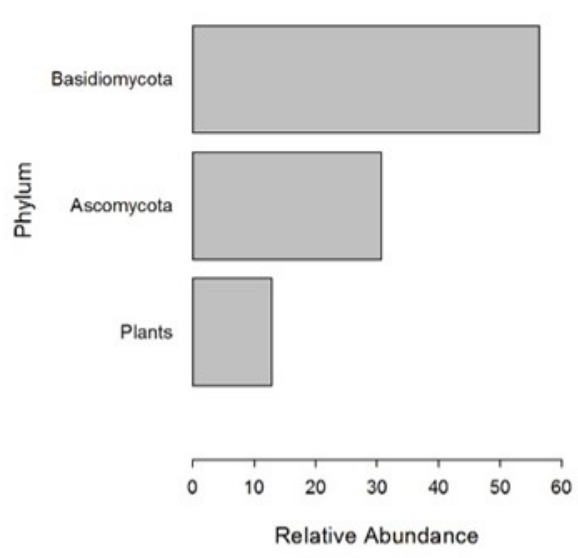

C

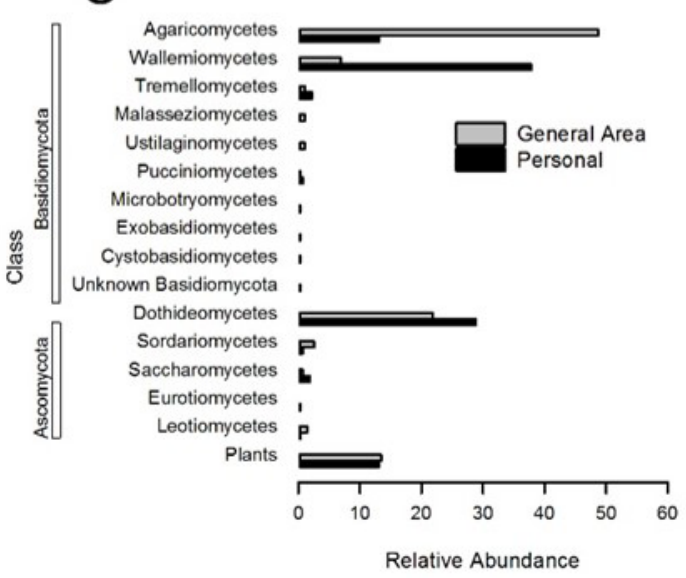

B

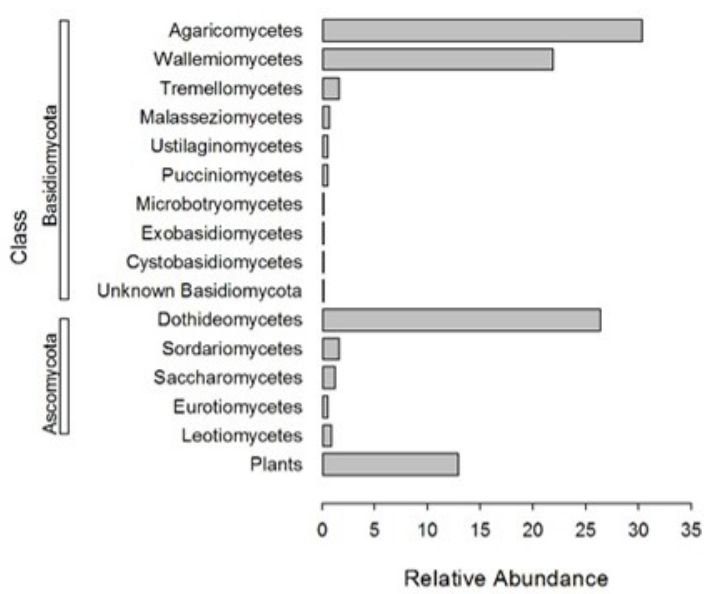

D

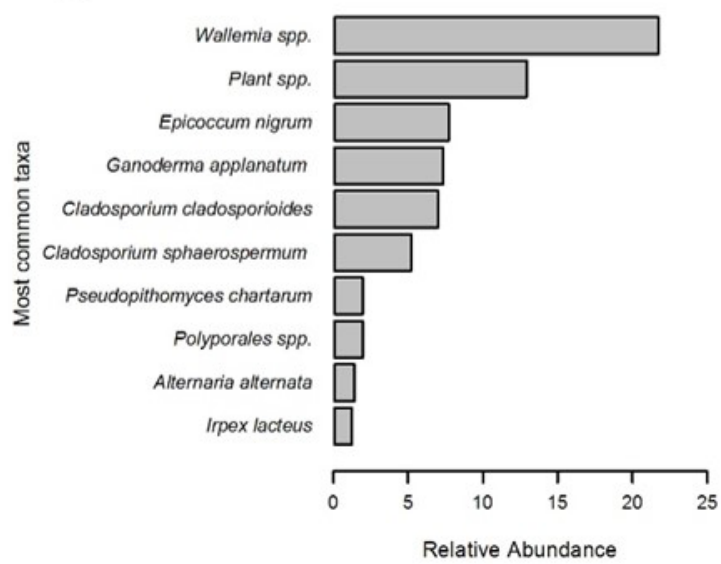

Figure 1. Four bar charts that depict fungal relative abundance by phylum (A), class (B), class by sampling location (C), and most common fungal taxa (D) identified following the August 2016 site visit. 


\section{Second Site Visit, April 2017}

Molecular analysis of personal and general area air samples revealed fungal DNA sequences derived from 806 sequences and were clustered into 131 taxonomic units derived from fungi (125) and plants (6). Figures 2A-2D are horizontal bar graphs showing the relative abundance by phylum (2A), class (2B), class according to sampling location (2C), and most common taxa (2D). The fungal sequences were placed in the Basidiomycota $(45 \%)$ and the Ascomycota (19\%) (Figure 2A). Plant-derived sequences accounted for 37\% of all identified second site visit sequences.

Figure 2B shows the relative abundance of classes derived from the two most prevalent fungal phyla, the Ascomycota and Basidiomycota. The Agaricomycetes (Basidiomycota) was the most abundant fungal class and accounted for $37 \%$ of sequences. The green plants were also detected in high relative abundance and accounted for $37 \%$ of all sequences. Compared to the first site visit, the fungal classes Cystobasidiomycetes, Ustilaginomycetes, and Wallemiomycetes were not identified during the second site visit. Analysis of the general area and personal air samples showed that Agaricomycetes sequences were predominantly associated with general area samples as was shown in the first site visit analysis; however, plant sequences primarily derived from Cannabis sativa accounted for $80 \%$ of all sequences identified in personal air samples (Figure 2D). These data suggest that the overall fungal burden was reduced compared to the first site visit conducted in August 2016. These data were subsequently confirmed in a separate analysis using an alternate fungal-specific primer pair that suggested low concentrations of fungal DNA in the general area and personal air samples (data not shown). A combination of variables associated with seasonal differences (summer versus spring), reduced environmental fungal burden (early spring) as well as decreased cannabis production could be factors that resulted in a reduced fungal burden identified in the second site visit samples. 
A

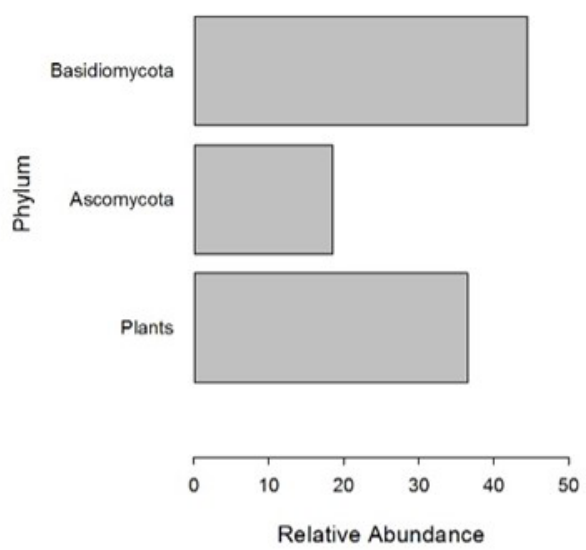

C

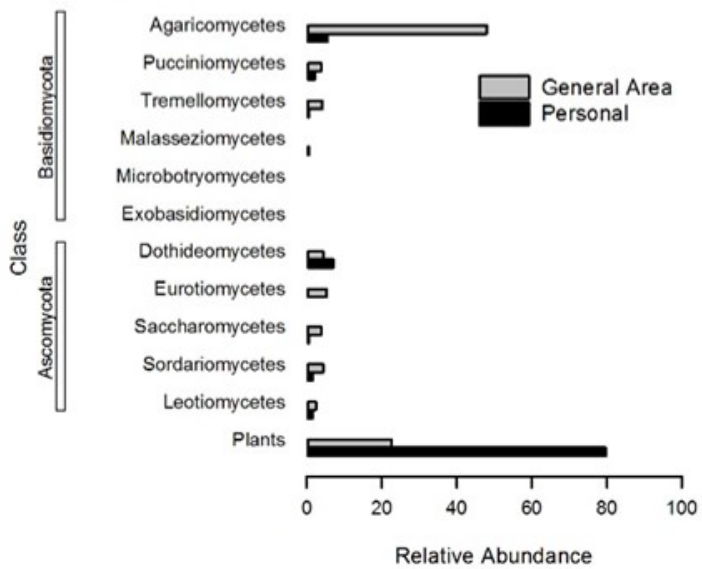

B
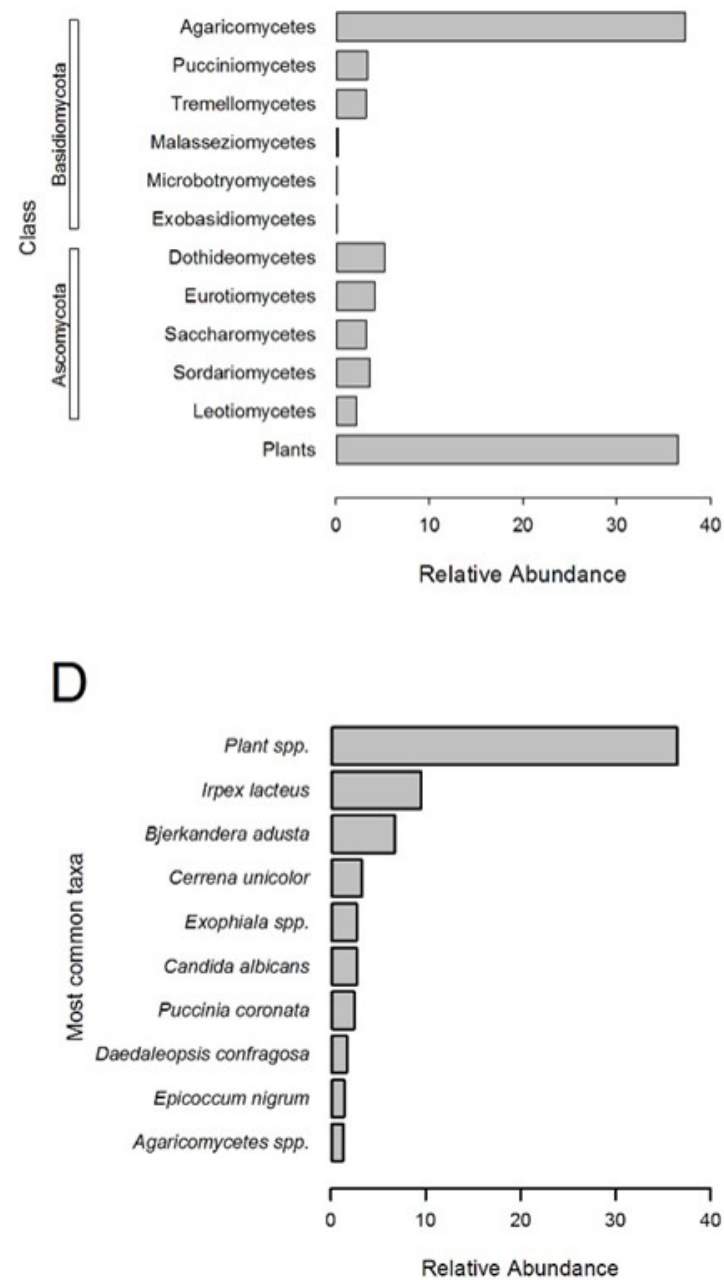

Figure 2. Four bar charts that depict the fungal relative abundance by phylum (A), class (B), class by sampling location (C), and most common fungal taxa (D) identified following the April 2017 site visit.

\section{Air Sampling for Endotoxins}

Personal air sampling results for endotoxin are shown in Table 7. Endotoxin concentrations ranged from none detected to 85 endotoxin units per cubic meter $\left(\mathrm{EU} / \mathrm{m}^{3}\right)$. Endotoxin concentrations were highest for all four employees on day 2. Both cultivator 1 and cultivator 2 endotoxin levels increased during day 2 when compared to day 1 . The only difference in job tasks was both cultivators moved numerous plants on day 2 and did not move plants on day 1. While neither day 2 sample exceeded the Dutch Expert Committee on Occupational Safety (DECOS) recommended limit of $90 \mathrm{EU} / \mathrm{m}^{3}$ [DECOS 2010], the marked increase and relatively high levels indicates a potential for exposures to exceed the DECOS recommended limit. No OELs for endotoxin have been established in the United States. 
Table 7. Personal air samples for endotoxins in August 2016*

\begin{tabular}{|c|c|c|c|}
\hline Job/Activity & $\begin{array}{l}\text { Sample time } \\
\text { (minutes) }\end{array}$ & $\begin{array}{l}\text { Total volume } \\
\text { (liters) }\end{array}$ & $\begin{array}{c}\text { Concentration } \\
\left(E \cup / m^{3}\right)\end{array}$ \\
\hline \multicolumn{4}{|l|}{ Day One } \\
\hline Cultivator 1 & 489 & 881 & 15 \\
\hline Cultivator 2 & 382 & 726 & 5.4 \\
\hline Packer & 323 & 592 & ND \\
\hline Chemist & 279 & 510 & ND \\
\hline \multicolumn{4}{|l|}{ Day Two } \\
\hline Cultivator 1 & 478 & 932 & 85 \\
\hline Cultivator 2 & 378 & 745 & 62 \\
\hline Packer & Pump failure & - & - \\
\hline Chemist & 250 & 493 & 1.1 \\
\hline ACGIH TLV & & & NA \\
\hline NIOSH REL & & & NA \\
\hline OSHA PEL & & & NA \\
\hline DECOS & & & 90 \\
\hline \multicolumn{4}{|c|}{ NA $=$ Not applicable } \\
\hline \multicolumn{4}{|c|}{ PEL = Permissible exposure limit } \\
\hline${ }^{*}$ The endotoxin & $m^{3}$. & & \\
\hline
\end{tabular}

Because of air sampling pump failures during collection of the day 2 sample on the packer, we were unable to determine an endotoxin concentration. The day 1 endotoxin sample for this job detected no endotoxins.

We also collected area endotoxin samples throughout the facility including the outdoor hoop houses. All 12 endotoxin samples had detectable concentrations. Table 8 shows the results for all area endotoxin samples. This highest endotoxin concentration was in the grinding room on day $2\left(94 \mathrm{EU} / \mathrm{m}^{3}\right)$. The only grinding operation was approximately 45 minutes long on day 2. Because this was an area sample that does not directly correspond to personal exposure, we cannot compare the result to the DECOS exposure limit of $90 \mathrm{EU} / \mathrm{m}^{3}$. However, this sample result indicates that if grinding tasks were performed for longer periods of time, employees could potentially be overexposed to endotoxins. We were unable to evaluate the grinding task during our second visit because the grinder was being dismantled and moved to another facility.

The grinding operator wore a $3 \mathrm{M}^{\mathrm{TM}} 6000$ series tight-fitting thermoplastic elastomer halfmask respirator with a P100 particulate filter. However, we observed that the operator had a full beard, which would prevent the respirator from fitting properly and providing protection. The company did not have a respiratory protection program. 
Table 8. Area air sampling for endotoxins in August 2016

\begin{tabular}{lccc}
\hline Job/Activity & $\begin{array}{c}\text { Sample time } \\
\text { (minutes) }\end{array}$ & $\begin{array}{c}\text { Total volume } \\
\text { (liters) }\end{array}$ & $\begin{array}{c}\text { Concentration } \\
(\text { EU/m })^{*}\end{array}$ \\
\hline Day 1 & & & \\
Vegetation room & 468 & 849 & 4.4 \\
Clone room & 467 & 853 & 2.1 \\
Greenhouse 1 & 464 & 866 & 10 \\
Hoop house C & 466 & 834 & 2.5 \\
Breakroom & 228 & 426 & 2.4 \\
Day 2 & & & \\
Vegetation room & 447 & 863 & 3.9 \\
Clone room & 445 & 801 & 2.5 \\
Greenhouse 2 & 442 & 857 & 5.3 \\
Hoop house B & 441 & 869 & 2.4 \\
Hoop house C & 444 & 875 & 1.7 \\
Loading dock & 477 & 921 & 1.6 \\
Grinding room & 60 & 117 & NA \\
\hline ACGIH TLV & & & NA \\
NIOSH REL & & & NA \\
OSHA PEL & & & 90 \\
DECOS & & &
\end{tabular}

${ }^{*}$ The endotoxin MDC was $0.50 \mathrm{EU} / \mathrm{m}^{3}$.

The airborne endotoxin concentrations at the facility were below those found in other agricultural settings, such as an indoor flower greenhouse with 38 employees (range: 0.84 to $1,100 \mathrm{EU} / \mathrm{m}^{3}$ ); two indoor herb processing plants with 70 and 90 employees (median endotoxin concentration: $3 \times 10^{5} \mathrm{EU} / \mathrm{m}^{3}$ ); four peppermint and nine chamomile herb farm indoor processing operations (median for endotoxin peppermint farms: $1 \times 10^{6} \mathrm{EU} / \mathrm{m}^{3}$; median endotoxin for chamomile farms: $1.8 \times 10^{4} \mathrm{EU} / \mathrm{m}^{3}$ ); and an indoor hemp processing plant with seven employees (mean endotoxin concentration: $1.9 \times 10^{4} \mathrm{EU} / \mathrm{m}^{3}$ ) [Dutkiewicz et al. 2001; Fishwick et al. 2001; Skórska et al. 2005; Thilsing et al. 2015].

\section{Particle Size Concentrations During Grinding}

Particle size concentration measurements were taken in the grinding room throughout the day on day 2 and the data was logged every 60 seconds. A single grinding task operation was done for 45 minutes in the afternoon. The grinding task corresponded to the highest endotoxin area sample result. Table 9 shows the particle concentrations, by size range, during the grinding task. 
Table 9. Grinding task measurements in August 2016*

\begin{tabular}{lccc}
\hline Particle size & $\begin{array}{c}\text { Grinding task } \\
\text { average* } \\
\left(\mathrm{mg} / \mathrm{m}^{3}\right)\end{array}$ & $\begin{array}{c}\text { Minimum } \\
\left(\mathrm{mg} / \mathrm{m}^{3}\right)\end{array}$ & $\begin{array}{c}\text { Maximum } \\
\left(\mathrm{mg} / \mathrm{m}^{3}\right)\end{array}$ \\
\hline $\mathrm{PM}_{1}$ & 0.67 & 0.01 & 3.87 \\
$\mathrm{PM}_{2.5}$ & 0.73 & 0.01 & 4.13 \\
Respirable & 0.78 & 0.01 & 4.4 \\
$\mathrm{PM}_{10}$ & 1.2 & 0.01 & 6.74 \\
Total & 3.4 & 0.01 & 20.5 \\
\hline
\end{tabular}

*Approximately 45-minute sample

Particle size concentrations measured prior to the task were used to establish background concentrations. Particle concentrations prior to the grinding tasks were very low. After the grinding task, particle concentrations returned to background levels in about 30-60 minutes. Figure 3 illustrates the grinding room concentrations throughout the day including the grinding task in the afternoon.

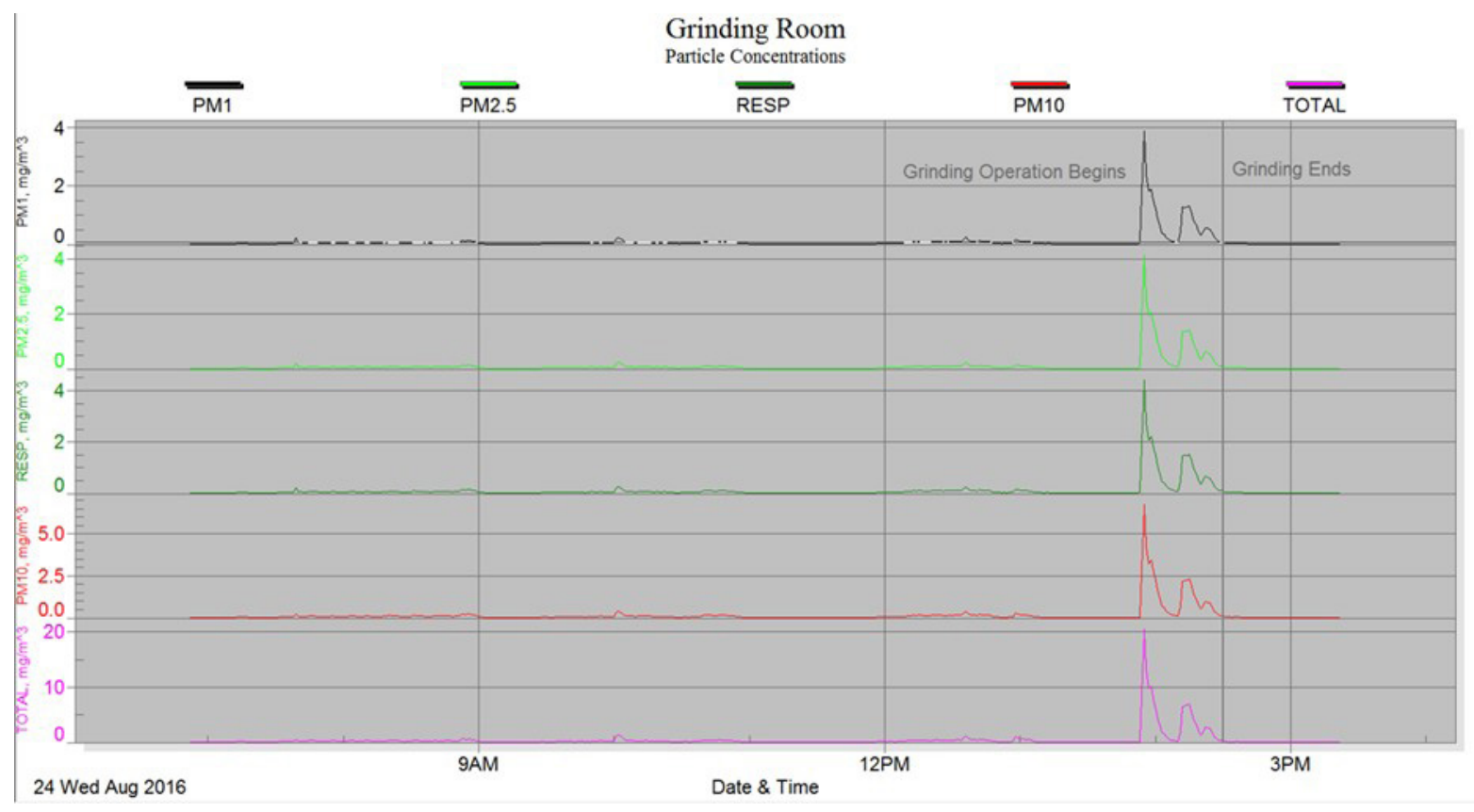

Figure 3. Real-time particle size concentrations for PM1, PM2.5, respirable (RESP), PM10, and total size ranges in the grinding room. 


\section{Workplace Observations}

The number of cannabis plants being grown had declined between our two visits. When we returned in April 2017, no plants were growing in the hoop houses and other areas, and the breezeway area was now the main growing area. The carbon dioxide extraction process was not operational during either visit.

In our April 2017 visit, we observed that the decarboxylation process, previously exhausted directly into the loading dock area, was now exhausted during baking. A vacuum pump was used to create negative pressure inside the oven. The oven exhaust ports had several feet of flexible tubing connected, which ran under a garage door and outside of the building (Figure 4). The vacuum pump was running the entire time during the heating portion of the activity and turned off when the product was removed. When the employee first opened the oven door to remove the baked cannabis product, we observed clouds of steam and vapor flowing out of the oven. The employee stepped back several feet during this time and allowed the vapor cloud to dissipate before reaching into the oven and retrieving pans of cannabis. The door handle to the oven was missing. The employee wore double nitrile gloves and oven mitts during this part of the process. We noticed a cannabis odor in the area when the employee opened the oven and retrieved the pans of baked cannabis.

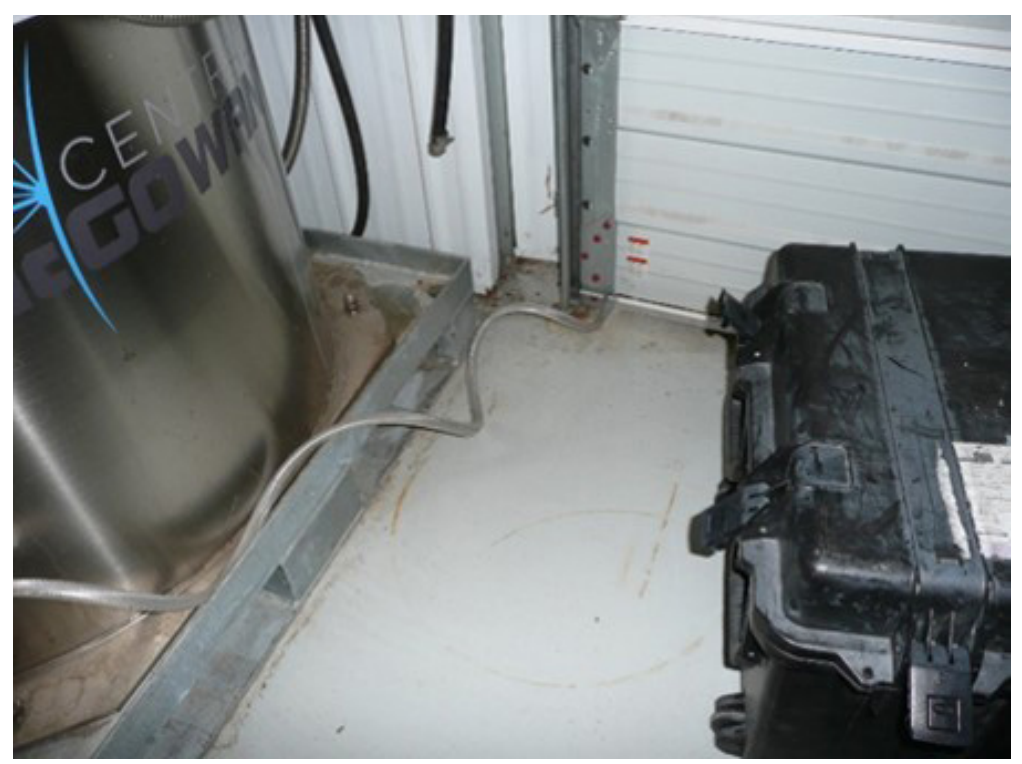

Figure 4. Tubing running from the decarboxylation oven exhaust port to outside the building. 


\section{Medical Interviews}

We interviewed 12 of 13 (92\%) employees that were present during our first site visit. Of the 12 employees interviewed, 11 were male and 11 were Caucasian. The average age of employees was 38 years (range: 24-55 years), the average amount of time working at the facility was 1 year, 2 months (range: 2 months-1 year, 10 months), and the average number of hours worked a week was 42 hours (range: 24-55 hours).

\section{Job Tasks}

We read a list of job tasks common to the cannabis industry and asked employees to indicate whether the tasks were part of their responsibilities. These tasks included inventory $(n=9)$, harvesting $(n=7)$, maintenance $(n=7)$, waste disposal $(n=7)$, packaging $(n=6)$, cultivation $(n=5)$, trimming $(n=4)$, cloning $(n=4)$, flushing $(n=4)$, stalking $(n=4)$, examining plants $(n=4)$, feeding plants $(n=3)$, topping $(n=3)$, pest control $(n=3)$, and transplanting $(n=2)$. When asked an open-ended question about "other" job tasks, some employees reported stripping plants, grinding plant matter, extraction, security tasks, product analysis, and wiring and system setup.

\section{Injuries at Work}

Of the 12 interviewed employees, 3 reported being injured on the job. The injuries included back strain, debris in an eye, and a laceration. All 3 injuries resulted in a visit to a healthcare provider, but none of them resulted in missed work or reassignment to different work tasks.

\section{Personal Protective Equipment}

We asked employees an open-ended question about the type of PPE they typically wear on the job. Of the 12 interviewed employees, 10 reported wearing PPE. The most commonly reported PPE was nitrile gloves $(n=9)$, followed by safety glasses or goggles $(n=8)$, dust mask $(n=4)$, respirator $(n=3)$, face shield $(n=3)$, smock $(n=3)$, enclosed toe shoes $(n=1)$, steel toed shoes $(n=1)$, and rubber boots $(n=1)$.

\section{Work-related Health Symptoms}

We read employees a list of physical and mental health symptoms, asking them to indicate whether they had experienced any in the past 4 weeks that they thought were work related. All items were given a yes/no response format. The most frequently reported symptoms were red or irritated eyes $(n=4)$, hand or wrist pain $(n=3)$, and stuffy nose or sinus problems $(n=3)$. Other symptoms were reported by 2 or fewer employees and are not listed here to maintain employee confidentiality.

\section{Work-related Safety Concerns}

Employees were asked an open-ended question to describe work-related safety concerns. Of the 12 employees interviewed, 4 indicated that they had safety concerns. Safety concerns included working with high pressure carbon dioxide, exit doors needing a badge to unlock for egress, ergonomic concerns in general, and working with large amounts of solvents. 


\section{Job Stress}

Employees were asked to rate their level of job stress on a scale from 0 (as low as it can be) to 10 (as high as it can be). Responses of 0-3 indicated low job stress, 4-6 indicated moderate job stress, and scores of 7 or greater indicated high job stress [Clark et al. 2011]. The average job stress score was 4.1 (range: $0-7$ ), indicating moderate job stress overall. On the basis of individual stress scores, five employees indicated low job stress, four indicated moderate job stress, and three indicated high job stress.

Employees were asked an open-ended question to describe the major source(s) of stress in their jobs. Five employees reported a heavy workload as major stressor. Other stressors were reported by two or fewer employees and are not described to maintain employee confidentiality.

\section{Physical and Psychosocial Working Conditions}

We used a combination of items from an occupational health survey [Weel and Fortuin 1998] and items developed specifically for this health hazard evaluation to ask about physical working conditions and psychosocial factors at work. All items were given a yes/no response format. Table 10 includes the physical working conditions that three or more employees indicated made them uncomfortable at work. The most frequently reported conditions making employees uncomfortable at work were heat and dust or dirt.

Table 10. Frequency of affirmative responses to physical working conditions items $(n=12)$

\begin{tabular}{lc}
\hline Working conditions items & Frequency \\
\hline $\begin{array}{l}\text { During your work, are you made } \\
\text { uncomfortable by: }\end{array}$ \\
$\quad$ Heat? & 4 \\
Dust/dirt? & 4 \\
Lengthy standing? & 3 \\
Lengthy periods of repetitive motions? & 3 \\
Loud noise? & 3 \\
Bad smells/odors? & 3 \\
\hline
\end{tabular}


Table 11 shows the number of employees who responded "yes" to the psychosocial items. Overall, most employees reported positive perceptions of the psychosocial work environment. Most employees $(n=7)$ reported that they have to perform tasks that are not part of their job description. Some employees reported that their jobs are at times more difficult due to coworkers not doing their jobs correctly $(n=5)$, or because of coworker absences $(n=4)$. Three employees reported that their job interferes with their private or family life.

Table 11. Employee responses to psychosocial items $(n=12)$

\begin{tabular}{lc}
\hline Psychosocial item & $\begin{array}{c}\text { Frequency of } \\
\text { "yes" } \\
\text { Do you need to spend a lot of time being alert at work? }\end{array}$ \\
\hline Do you feel free to report health or safety concerns at work? & 12 \\
Does your employer encourage you to stay home if you are ill? & 12 \\
Can you take a break if you need to? & 12 \\
Can you usually manage to take a day off easily? & 11 \\
Is it clear to you what your responsibilities are at work? & 11 \\
Do you normally enjoy your work? & 11 \\
Do you have enough variation in your work? & 11 \\
Do you feel appreciated in your job? & 11 \\
Is your work usually well organized? & 10 \\
Do your supervisors listen to what you have to say? & 10 \\
Do you always have the tools necessary to complete your work? & 10 \\
Do you believe you were trained well for your job? & 10 \\
Do you have a lot of say or get to make many decisions as part of your job? & 10 \\
Do you think your pay is fair? & 10 \\
Do you trust your employer to look out for your well-being? & 9 \\
Does this work offer you sufficient job security? & 9 \\
Are you well-informed about the goals and results of your work? & 9 \\
Does your work require a lot of thinking? & 9 \\
Do you often have to do something which isn't part of your job description?* & 9 \\
Is your work highly physical? & 9 \\
Is your work made more difficult due to other people not doing their job properly?* & 5 \\
Do you have fixed working hours? & 5 \\
Is your work made more difficult due to other people being absent?* & 5 \\
Do you regularly work under short deadlines?* & 5 \\
Does your work interfere with your private or family life?* & 3 \\
\hline
\end{tabular}

*Item has negative connotation 


\section{Questionnaires and Spirometry}

With the identification of diacetyl and 2,3-pentanedione, we returned in April 2017 to further inquire about symptoms and diagnoses related to allergic and respiratory health and evaluate employee lung function. Lung function results, in the form of spirometry, were first categorized as abnormal and normal, with abnormal results falling below the predicted values. Only one employee was identified as having an abnormal result consistent with a mild restrictive pattern. However, the employee had non-occupational factors that likely contributed to a restrictive pattern on spirometry testing; therefore, it is unlikely that the employee's low FVC was solely from occupational sources. No employees exhibited either an obstructive or mixed pattern.

Of 12 employees present during our second visit, 9 (75\%) participated in the medical questionnaire. Table 12 below describes their demographics.

Table 12. Demographics of medical survey participants ( $\mathrm{n}=9$ unless otherwise indicated)

\begin{tabular}{lc}
\hline Characteristic & Value \\
\hline Age, years, mean (range) & $40(24-57)$ \\
Male, $\mathrm{n}(\%)$ & $8(89)$ \\
Race, $\mathrm{n}(\%)$ & \\
$\quad$ White & $8(89)$ \\
Asian & $1(11)$ \\
Body mass index ( $\mathrm{n}=8)$, mean (range) & $32(24-43)$ \\
Tobacco smoking status, $\mathrm{n}(\%)$ & \\
Current & $1(11)$ \\
Former & $3(33)$ \\
Never & $5(55)$ \\
\hline
\end{tabular}

\section{Job Tasks}

On the basis of observations and interviews from our first visit, we derived a set of job tasks routinely performed in areas where ground organic dust, diacetyl and 2,3-pentanedione were identified. We asked about performing these tasks over the last 30-day period. The tasks performed and amount of time worked per week are provided in Table 13 below. 
Table 13. Frequency and time spent performing cannabis job tasks in last 30 days

\begin{tabular}{lcc}
\hline Job task & $\begin{array}{c}\text { Number of } \\
\text { employees }\end{array}$ & $\begin{array}{c}\text { Mean hours worked } \\
\text { per week (range) }\end{array}$ \\
\hline Extraction & 3 & $5(2-8)$ \\
Decarboxylation & 3 & $2(1-4)$ \\
De-stemming & 4 & $4(1-8)$ \\
Grinding & 1 & 1 \\
Laboratory work & 4 & $8(3-20)$ \\
Packaging & 6 & $12(1-40)$ \\
Shipping & 4 & $3(1-8)$ \\
Cultivation & 5 & $16(1-40)$ \\
\hline
\end{tabular}

\section{Work-related Health Symptoms}

Work-related symptoms (defined as symptoms that improved away from the facility or were aggravated by work at the facility) were reported by four $(45 \%)$ employees. Two or fewer participants noted that dust at work caused or aggravated their symptoms during the following activities: destemming, grinding, decarboxylation, and facility maintenance. Other work-related symptoms reported by two or fewer participants included wheezing, nasal symptoms, eye irritation, sinus problems, musculoskeletal pain, and fatigue.

Employees were asked about chronic medical conditions that affect breathing or can result in a cough. Four $(45 \%)$ employees noted a history of hay fever or nasal allergies. Two or fewer employees noted a history of eczema, dermatitis or skin allergy, and gastroesophageal reflux disease. Employees reported the onset of hay fever or nasal allergies and eczema, dermatitis, or a skin allergy after starting work at this facility. Employees denied having heart disease, chronic bronchitis, emphysema, chronic obstructive pulmonary disease, pneumonitis (chemical and hypersensitivity), obliterative bronchiolitis, interstitial lung disease, vocal cord dysfunction, or asthma.

\section{Spirometry}

The results of lung function tests are displayed in Table 14. All but one participant $(\mathrm{n}=8)$ completing the medical questionnaire were included in spirometry testing. All spirometry tests were interpretable. One participant had an abnormal spirometry test result, representing a mild restrictive pattern. The mean predicted values for $\mathrm{FEV}_{1}$ and $\mathrm{FVC}$ were normal.

Table 14. Results of spirometry of medical survey participants

\begin{tabular}{lc} 
Spirometry $(\mathrm{n}=8)$ & \\
\hline FEV1 \% predicted, mean (range) & $97(82-112)$ \\
FVC \% predicted, mean (range) & $97(81-111)$ \\
FEV $_{1} /$ FVC \%, mean (range) & $100(87-107)$ \\
Restriction, $\mathrm{n}(\%)$ & $1(13)$ \\
Obstruction, $\mathrm{n}(\%)$ & $0(0)$ \\
Mixed, $\mathrm{n}(\%)$ & $0(0)$ \\
\hline
\end{tabular}




\section{Conclusions}

We evaluated hazards associated with harvesting and processing cannabis at an indoor/ outdoor grow facility. Surface wipe concentrations indicate the potential exposure to not only $\triangle 9$-THC, but also to other cannabis components such as $\triangle 9-\mathrm{THCA}, \mathrm{CBD}$, and CBN. However, the health implications for occupational exposure to these cannabis components are unknown. Our findings indicate the potential for diacetyl and 2,3-pentanedione exposures, especially during decarboxylation, but the results were inconclusive because of the differences between the two sampling and analytical methods. We also found airborne exposures to microbial fungus and endotoxins that can increase the risk of allergic and respiratory symptoms. While numerous terpenes were found in the air, no oxidation products were detected. Employees reported moderate job stress overall, and the most frequently reported source of stress was heavy workload. Performing duties that are inconsistent with their role in the workplace was also a concern and may contribute to perceptions of heavy workload.

\section{Recommendations}

On the basis of our findings, we recommend the actions listed below. We encourage the medical cannabis facility to use a labor-management health and safety committee or working group to discuss our recommendations and develop an action plan. Those involved in the work can best set priorities and assess the feasibility of our recommendations for the specific situation at the grow facility.

Our recommendations are based on an approach known as the hierarchy of controls. This approach groups actions by their likely effectiveness in reducing or removing hazards. In most cases, the preferred approach is to eliminate hazardous materials or processes and install engineering controls to reduce exposure or shield employees. Until such controls are in place, or if they are not effective or feasible, administrative measures and PPE may be needed.

\section{Engineering Controls}

Engineering controls reduce employees' exposures by removing the hazard from the process or by placing a barrier between the hazard and the employee. Engineering controls protect employees effectively without placing primary responsibility of implementation on the employee.

1. Ensure that the decarboxylation oven vacuum pump is turned on and that the exhaust hose opening is outdoors for all decarboxylation activities.

2. Install local exhaust ventilation on the grinder to reduce exposures.

3. Move the decarboxylation oven to an area with less occupancy and foot traffic than the loading dock.

4. Fix or replace the oven handle on the decarboxylation oven. 


\section{Administrative Controls}

The term administrative controls refers to employer-dictated work practices and policies to reduce or prevent hazardous exposures. Their effectiveness depends on employer commitment and employee acceptance. Regular monitoring and reinforcement are necessary to ensure that policies and procedures are followed consistently.

1. Evaluate employee workload and obtain employee input regarding how it affects job stress and job satisfaction. Engage employees in discussion about whether workload could be better managed and how. Doing so can improve employee morale.

2. Define employee job roles clearly, and talk to employees about how to reduce having to perform duties outside of their role.

3. Hire additional employees, if possible, to reduce the workload for individuals.

4. Develop a cleaning schedule to remove cannabis components, such as THC, from work and tool surfaces.

5. Encourage employees to wash their hands with soap and water immediately after leaving the work area.

6. Encourage employees to report any work-related symptoms to their supervisor and to their healthcare provider.

7. Hire an ergonomist or request a new health hazard evaluation to perform an evaluation of job tasks and equipment.

8. Allow exit doors to be opened without a badge to facilitate evacuation in emergencies.

\section{Personal Protective Equipment}

Proper use of personal protective equipment requires a comprehensive program and a high level of employee involvement and commitment. The right personal protective equipment must be chosen for each hazard. Supporting programs such as training, change-out schedules, and medical assessment may be needed. Personal protective equipment should not be the sole method for controlling hazardous exposures. Rather, personal protective equipment should be used until effective engineering and administrative controls are in place.

1. Provide employees who choose to use filtering facepiece respirators on a voluntary basis with Appendix D from the OSHA respiratory protection standard 1910.134 (Information for Employees using Respirators When Not Required Under Standard). OSHA allows for voluntary use of respirators once the employer has determined that the respiratory protection is not necessary to protect the health of the worker and that the respirator itself does not present a health hazard if used during work. Other OSHA requirements for voluntary respirator use can be found at:

https://www.osha.gov/dte/library/respirators/major requirements.html.

2. Use a NIOSH-approved N95 disposable filtering facepiece respirator instead of a "dust mask." 


\section{Appendix A: Tables}

Table A1. Surface wipe sampling for cannabis compounds (ng per $100 \mathrm{~cm}^{2}$ ) in August 2016

\begin{tabular}{|c|c|c|c|c|c|}
\hline \multirow{2}{*}{ Location } & \multirow{2}{*}{$\frac{\Delta 9-\mathrm{THC} \text { only }}{\Delta 9-\mathrm{THC}}$} & \multicolumn{4}{|c|}{ Cannabinoid method } \\
\hline & & $\Delta 9-\mathrm{THC}$ & $\triangle 9-\mathrm{THCA}$ & CBD & CBN \\
\hline \multicolumn{6}{|l|}{ Loading dock } \\
\hline Workbench & 160 & ND & ND & ND & ND \\
\hline Workbench \#2 & 20 & ND & ND & ND & ND \\
\hline Decarboxylation oven desk & 53,000 & 17,000 & ND & {$[3,700]$} & {$[2,100]$} \\
\hline \multicolumn{6}{|l|}{ Vegetation room } \\
\hline Table under white board & 470 & ND & {$[5,300]$} & ND & ND \\
\hline Refrigerator door* & {$[7.8]$} & ND & ND & ND & ND \\
\hline $\begin{array}{l}\text { Greenhouse A door handle } \\
\quad(\text { Method } 1 \text { only })^{*}\end{array}$ & 270 & NA & NA & NA & NA \\
\hline 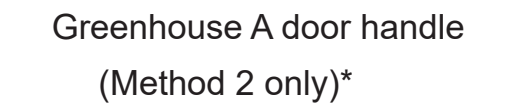 & NA & ND & {$[3,600]$} & ND & ND \\
\hline \multicolumn{6}{|l|}{ Greenhouse A } \\
\hline PVC pipe supporting plants* & 450 & ND & {$[4,100]$} & ND & ND \\
\hline Pallet jack* & 1,500 & ND & 9,500 & ND & ND \\
\hline Sink & 590 & {$[4,400]$} & 34,000 & ND & ND \\
\hline \multicolumn{6}{|l|}{ Greenhouse B } \\
\hline PVC pipe supporting plants* & 110 & ND & ND & ND & ND \\
\hline PVC pipe under filter* & {$[14]$} & ND & ND & ND & ND \\
\hline \multicolumn{6}{|l|}{ Breezeway } \\
\hline Storage cabinet workbench & ND & 8,000 & 140,000 & {$[5,200]$} & {$[6,400]$} \\
\hline Workbench near greenhouse & ND & ND & ND & ND & ND \\
\hline Mobile cart near back door & ND & ND & ND & ND & ND \\
\hline Storage crate-center of room & 14,000 & 15,000 & 62,000 & {$[3,900]$} & ND \\
\hline \multicolumn{6}{|l|}{ Breakroom } \\
\hline Counter near coffeemaker & 24 & ND & ND & ND & ND \\
\hline Counter in front of microwave & 71 & ND & {$[2,400]$} & ND & ND \\
\hline Table & 26 & ND & ND & ND & ND \\
\hline
\end{tabular}

*The $100 \mathrm{~cm}^{2}$ template could not be used so an estimated $100 \mathrm{~cm}^{2}$ was sampled.

Note: Values in brackets are between the LOD and LOQ. This means there is more uncertainty associated with the value. 
Table A2. Terpenes detected in whole air canister samples

\begin{tabular}{|c|c|}
\hline Compound name & Percent match* \\
\hline \multicolumn{2}{|l|}{ Monoterpenes } \\
\hline 3-Carene & 97 \\
\hline 4-Carene & 97 \\
\hline$\alpha$-Fenchene & 70 \\
\hline a-Phellandrine & 49 \\
\hline a-Pinene & 100 \\
\hline a-Terpinene & 96 \\
\hline$\alpha$-Terpinol & 90 \\
\hline$\alpha$-Terpinolene & 97 \\
\hline$\beta$-Ocimene & 46 \\
\hline$\beta$-Pinene & 91 \\
\hline$\beta$-Terpineol & 47 \\
\hline Cyclofenchene & 38 \\
\hline d-Limonene & 100 \\
\hline Fenchol & 94 \\
\hline Y-Terpinene & 96 \\
\hline \multicolumn{2}{|l|}{ Sesquiterpenes } \\
\hline a-Cubebene & 98 \\
\hline Bergamotene & 89 \\
\hline Caryophyllene & 99 \\
\hline Copaene & 99 \\
\hline Sativene & 86 \\
\hline Ylangene & 98 \\
\hline
\end{tabular}

*Percent match quality is a measure of how well an unknown mass spectrum fits a known library spectrum. Values given here use the 2014 NIST/EPA/NIH Mass Spectral Library (NIST 14). 
Table A3. Ozone concentration readings

\begin{tabular}{|c|c|c|}
\hline $\begin{array}{l}\text { Time } \\
\text { (Hour:minute) }\end{array}$ & $\begin{array}{l}\text { Concentration } \\
(\mathrm{ppb})\end{array}$ & Location \\
\hline \multicolumn{3}{|l|}{ Day 1} \\
\hline 06:39 & 25 & Outside \\
\hline 06:40 & 27 & Outside \\
\hline $06: 41$ & 28 & Outside \\
\hline $06: 42$ & 29 & Outside \\
\hline $06: 43$ & 27 & Outside \\
\hline $06: 44$ & 29 & Outside \\
\hline $06: 45$ & 28 & Outside \\
\hline $06: 46$ & 30 & Outside \\
\hline $06: 48$ & 29 & Outside \\
\hline 06:49 & 32 & Outside \\
\hline $06: 50$ & 22 & Interior \\
\hline $07: 54$ & 30 & Interior \\
\hline $14: 07$ & 18 & Interior \\
\hline $14: 12$ & 28 & Vegetation room \\
\hline $14: 16$ & 30 & Greenhouse A \\
\hline $14: 20$ & 18 & Interior \\
\hline $14: 24$ & 30 & Greenhouse B \\
\hline $14: 28$ & 32 & Outside \\
\hline \multicolumn{3}{|l|}{ Day 2} \\
\hline 06:19 & 24 & Interior \\
\hline $06: 20$ & 23 & Interior \\
\hline $06: 21$ & 22 & Interior \\
\hline $06: 22$ & 23 & Interior \\
\hline $06: 51$ & 26 & Vegetation room \\
\hline $06: 53$ & 16 & Greenhouse A \\
\hline $06: 55$ & 20 & Greenhouse B \\
\hline 07:04 & 27 & Outside \\
\hline 07:10 & 22 & Interior \\
\hline 10:09 & 10 & Interior \\
\hline $10: 10$ & 19 & Interior \\
\hline ACGIH TLV & \multicolumn{2}{|c|}{$0.05 \mathrm{ppm}(50 \mathrm{ppb})$ for heavy work } \\
\hline NIOSH REL & \multicolumn{2}{|c|}{0.1 ppm (100 ppb) } \\
\hline OSHA PEL & \multicolumn{2}{|c|}{0.1 ppm (100 ppb) } \\
\hline
\end{tabular}




\section{Appendix B: Medical Interview Form}

DOB

Sex

Time in cannabis industry $\mathrm{yrs} / \mathrm{mo}$

Time working for \#\#\#\# yrs/mo Ethnicity Job title

Job tasks: ${ }^{\square}$ Cultivation

${ }^{\square}$ Harvesting

$\square$ Trimming $\quad{ }^{\square}$ Topping

${ }^{\square}$ Maintenance

$\square$ Transplanting

${ }^{\square}$ Waste disposal ${ }^{\square}$ Organic pest control ${ }^{\square}$ Feeding plants

${ }^{\square}$ Cloning ${ }^{\square}$ Inventory ${ }^{\square}$ Flushing ${ }^{\square}$ Super cropping

${ }^{\square}$ Staking weak plants ${ }^{\square}$ Examining plants ${ }^{\square}$ Packaging

$\square$ Other

How many hours do you typically work at \#\#\#\# in a week?

Do you have any work-related safety concerns? YES NO Describe:

Have you been injured on the job? YES NO Describe:

If YES, did you see a health care provider? YES NO

If YES, did you miss time at work? YES NO

If YES, were you assigned to a different job?YES NO

What kind of PPE do you wear on the job? During what tasks?

Do you have any work-related health concerns? YES NO Describe: 
In the past 4 weeks, have you experienced any of the following symptoms that might be work-related?

\begin{tabular}{|l|l|l|l|l|l|}
\hline Hand or wrist pain & Yes & No & Changes in appetite & Yes & No \\
\hline Back pain & Yes & No & Stomach or digestive problems & Yes & No \\
\hline Shoulder pain & Yes & No & Difficulty hearing & Yes & No \\
\hline Leg pain & Yes & No & Runny nose & Yes & No \\
\hline Foot pain & Yes & No & Stuffy nose or sinus problems & Yes & No \\
\hline Rash on skin & Yes & No & Respiratory problems & Yes & No \\
\hline Hives & Yes & No & Difficulty remembering things & Yes & No \\
\hline Headaches & Yes & No & Difficulty concentrating & Yes & No \\
\hline Lightheadedness & Yes & No & Frequent changes in mood & Yes & No \\
\hline Heart palpitations & Yes & No & Depression & Yes & No \\
\hline Chest tightness & Yes & No & Anxiety & Yes & No \\
\hline Shortness of breath & Yes & No & Fatigue & Yes & No \\
\hline Sore throat & Yes & No & Difficulty sleeping & Yes & No \\
\hline Red or irritated eyes & Yes & No & Unexplained fevers & Yes & No \\
\hline
\end{tabular}

Other symptoms?

How would you rate your overall level of job stress on a scale from 0 to 10 , where 0 is no stress at all, and 10 is severe stress?

What, if any, are the major sources of stress on your job?

Now I'd like to ask you some questions related to your work. Please answer YES or NO. 


\begin{tabular}{|c|c|c|}
\hline During your work, are you made uncomfortable by: & Yes & No \\
\hline Lengthy sitting & Yes & No \\
\hline Lengthy standing & Yes & No \\
\hline Lifting or carrying & Yes & No \\
\hline Lengthy periods of being in the same physical position & Yes & No \\
\hline Bending down regularly & Yes & No \\
\hline Reaching up regularly & Yes & No \\
\hline Lengthy periods of repetitive motions & Yes & No \\
\hline Loud noise & Yes & No \\
\hline Cold & Yes & No \\
\hline Heat & Yes & No \\
\hline Changes in temperature & Yes & No \\
\hline Dry air & Yes & No \\
\hline Damp air & Yes & No \\
\hline Lack of fresh air & Yes & No \\
\hline Bad smells/odors & Yes & No \\
\hline Stagnant water & Yes & No \\
\hline Bright light & Yes & No \\
\hline Dust/dirt & Yes & No \\
\hline Pests & Yes & No \\
\hline Is your work highly physical? & Yes & No \\
\hline Do you have enough variation in your work? & Yes & No \\
\hline Does your work require a lot of thinking? & Yes & No \\
\hline Do you need to spend a lot of time being alert at work? & Yes & No \\
\hline Do you always have the tools necessary to complete your work? & Yes & No \\
\hline Do you regularly work under short deadlines? & Yes & No \\
\hline Do you believe you were trained well for your job? & Yes & No \\
\hline Do you normally enjoy your work? & Yes & No \\
\hline Do you have a lot of say or get to make many decisions as part of your job? & Yes & No \\
\hline Do you often have to do something which isn't part of your job description? & Yes & No \\
\hline Is it clear to you what your responsibilities are at work? & Yes & No \\
\hline Is work usually well organized? & Yes & No \\
\hline Do your supervisors listen to what you have to say? & Yes & No \\
\hline Do you feel free to report health or safety concerns at work? & Yes & No \\
\hline Do you have poor relations with any of your coworkers? & Yes & No \\
\hline Do you have poor relations with any of your supervisors? & Yes & No \\
\hline Are you well-informed about the goals and results of your work? & Yes & No \\
\hline Is your work made more difficult due to other people being absent? & Yes & No \\
\hline Is your work made more difficult due to other people not doing their job properly? & Yes & No \\
\hline Does this work offer you sufficient job security? & Yes & No \\
\hline Do you feel appreciated in your job? & Yes & No \\
\hline Do you think your pay is fair? & Yes & No \\
\hline Do you trust your employer to look out for your well-being? & Yes & No \\
\hline Do you have fixed working hours? & Yes & No \\
\hline Can you take a break if you need to? & Yes & No \\
\hline Can you usually manage to take a day off easily? & Yes & No \\
\hline Does your employer encourage you to stay home if you are ill? & Yes & No \\
\hline Does your work interfere with your private or family life? & Yes & No \\
\hline
\end{tabular}




\section{Behavioral History}

Do you now, or have you ever, smoked tobacco?

No Current (__ \# _ \# cigs/day) Past (__ \#yrs since quit)

Do you now, or have you ever, vaped? No Current Past (__ \#yrs since quit)

Do you drink alcohol? No Yes (__ \#drinks/day)

What hobbies, activities or jobs do you have outside of your employment with \#\#\#\#?

Outside of your job at this facility, have you worked with any of the following on a regular basis in the past month? (Check all that apply.)

$\square$ Solvents (any type)

$\square$ Paints, primers, or glaze

${ }^{\square}$ Industrial strength cleaning agents

$\checkmark$ Glues, adhesives, tape, etc.

$\checkmark$ Sealants or caulks

$\square$ Ceramic, plaster, or cement

$\checkmark$ Pesticides, herbicides, or fertilizers

$\square$ Wood

口 Other (specify:

$\checkmark$ I haven't worked with any of these in the past 12 months 


\section{Appendix C: Methods}

\section{Evacuated Canister Sample Method}

Evacuated canister sampling consisted of a 450-mL evacuated canister (stainless steel construction with an electropolished interior) equipped with restricted flow controller (15-minute or 6-hour duration) or an instantaneous flow controller that was designed for a short sampling duration ( $<30$ seconds). The canister air samples were analyzed using a preconcentrator/gas chromatograph/mass spectrometer system pursuant to a published method validation study [LeBouf et al. 2012], with the following modifications: the preconcentrator was a Entech Instruments, Inc. Model 7200, and three additional compounds, diacetyl, 2,3-pentanedione, and 2,3-hexanedione, were included. At present, the method is partially validated and being reviewed for inclusion in the NIOSH Manual of Analytical Methods.

\section{Terpene and Oxygenated Compounds}

Details of the canister analysis procedure were described previously [LeBouf et al. 2012]. Briefly, canisters were concentrated prior to analysis using an Entech Instruments, Inc. Model 7032 autosampler, with a $100^{\circ} \mathrm{C}$ transfer line attached to a Entech Instruments, Inc. Model 7032 preconcentrator. The preconcentrator was coupled with a Agilent Technologies, Inc. 7890/5977 GC-MS system with a Restek Corporation Rxi ${ }^{\circledR}-1 \mathrm{~ms}$ capillary column $60 \mathrm{~m}$ long $\times 0.32 \mathrm{~mm}$ ID x $1 \mu \mathrm{m}$ film thickness. Preconcentration conditions were modified for cold trap dehydration at the following modules: module 1 (empty) at $-40^{\circ} \mathrm{C}$, desorbed at $10^{\circ} \mathrm{C}$, and baked at $150^{\circ} \mathrm{C}$ for 7 minutes; module 2 (Tenax $\AA$ sorbent) focused at $-40^{\circ} \mathrm{C}$, desorbed at $230^{\circ} \mathrm{C}$, and baked at $230^{\circ} \mathrm{C}$; and module 3 (focuser) focused at $-150^{\circ} \mathrm{C}$. GC conditions were oven temperature program set to $35^{\circ} \mathrm{C}$ for $5 \mathrm{~min}$, followed by $6^{\circ} \mathrm{C} \mathrm{min}{ }^{-1}$ ramp to $95^{\circ} \mathrm{C}$, then $10^{\circ} \mathrm{C} \mathrm{min}^{-1}$ ramp to $140^{\circ} \mathrm{C}$, followed by a $15^{\circ} \mathrm{C} \mathrm{min}^{-1}$ ramp to a final temperature of $220^{\circ} \mathrm{C}$, which was held for 5.17 minutes; injector temperature was set to $150^{\circ} \mathrm{C}$ with a splitless injection; and column flow rate was set to $1.5 \mathrm{~mL} \mathrm{~min}^{-1}$. Mass spectrometer analysis conditions were scan mode 35-350 amu (selected ion monitoring for diacetyl, 2,3-pentanedione, and 2,3-hexanedione); solvent delay to $3.77 \mathrm{~min}$; source temperature at $300^{\circ} \mathrm{C}$; and, quadrupole temperature at $150^{\circ} \mathrm{C}$. A one-point calibration check standard (10 ppb) and instrument blank (UHP nitrogen gas) were analyzed with each set of samples within a 24-hour period. Agilent Technologies, Inc. MSD Chemstation D.02.00.275 was used for data acquisition. Chromatograms were integrated, and the resulting data was transferred to spreadsheets for subsequent blank correction and data handling prior to statistical analysis; final concentrations were calculated based on the response of the closest internal standard (bromochloromethane, 1,4-difluorobenzene, and chlorobenzene-d5).

For all carbonyl samples, after collection, the water was decanted into $40-\mathrm{mL}$ vials, then 100 microliter $(\mu \mathrm{L})$ aqueous $250 \mathrm{mM}$ O-tert-butylhydroxylamine hydrochloride was added (TBOX, Sigma Aldrich) [Jackson et al. 2016]. After being shipped to the lab, the vials were placed in a heated water bath at $70^{\circ} \mathrm{C}$ for 2 hours. The vials were removed from the water bath and allowed to cool to room temperature, then $0.5 \mathrm{~mL}$ of toluene was added to the vial. The vial was then shaken for 30 seconds and allowed to separate into 
organic and aqueous layers. Next, $100 \mu \mathrm{L}$ of the toluene layer was removed with a pipette and placed in a $2 \mathrm{~mL}$ autosampler vial with a Restek $100 \mu \mathrm{L}$ glass insert. Then $1 \mu \mathrm{L}$ of the TBOX-derivatized extract was analyzed using an Agilent 240 Internal EI/CI ion trap mass. Compound separation was achieved using an Agilent DB-5MS (0.25 mm I.D., $30 \mathrm{~m}$ long, $0.25 \mu \mathrm{m}$ film thickness) column and the following GC oven parameters: $40^{\circ} \mathrm{C}$ for $2 \mathrm{~min}$, then $5^{\circ} \mathrm{C} \mathrm{m^{-1 }}$ to $200^{\circ} \mathrm{C}$, then $25^{\circ} \mathrm{C} \mathrm{min}^{-1}$ to $280^{\circ} \mathrm{C}$ and held for $5 \mathrm{~min}$. One $\mu \mathrm{L}$ of each sample was injected in the splitless mode with the $\mathrm{GC}$ injector at $130^{\circ} \mathrm{C}$. The mass spectrometer was tuned using perfluorotribuylamine (FC-43). Full-scan EI ionization spectra were collected from m/z 40-1000.

\section{Air Sampling for Microbial Biodiversity Analysis}

We collected aerosols at 2 liters per minute using a two-stage sampler with two cyclones depositing into a $15-\mathrm{mL}$ polypropylene tube, a $1.5-\mathrm{mL}$ microcentrifuge tube and onto a mixed cellulose ester filter. The bioaerosol samplers allowed for the collection of particles across three size fractions: $>4.1$ micrometers, 1.0-4.1 micrometers, and $<1.0$ micrometer aerodynamic diameter. The three size cut samples taken with each bioaerosol sampler were aggregated for genomic DNA analysis.

\section{Genomic DNA Extraction from Air Samples}

We processed air samples for fungal DNA extraction using the Roche High Pure Polymerase Chain Reaction (PCR) Template kit as previously described [Green et al. 2016]. For air samples, including field and media blank controls, we combined each stage from the NIOSH BC251 air sampler prior to DNA extraction. We sectioned the after filter into six pieces with a scalpel using aseptic methods. We placed these pieces into a 2-mL bead-beater tube that contained 300 milligrams of glass beads as described above. We placed the tubes in liquid nitrogen for 30 seconds and processed in a bead beater for 30 seconds. This process was repeated one more time. The High Pure PCR Template kit lysis buffer $(650 \mu \mathrm{L})$ was then sequentially added to the first and second stage tubes and vortexed to collect the fungal DNA from the samples. The lysis buffer was added to the 2-mL bead-beater tube that contained the macerated filter material. We processed the tubes with a bead beater for 30 seconds and then centrifuged for 1 minute at $20,000 \times \mathrm{g}$, a measure of relative centrifugal force. We collected the supernatant and incubated with $40 \mu \mathrm{L}$ Cell Lytic B lysis reagent (Sigma Aldrich) for 15 minutes at $37^{\circ} \mathrm{C}$. We mixed the sample with the kit's binding buffer $(200 \mu \mathrm{L})$ and proteinase $\mathrm{K}(40 \mu \mathrm{L})$ and incubated at $70^{\circ} \mathrm{C}$ for 10 minutes. We washed and eluted the sample as recommended by the manufacturer.

\section{Fungal Internal Transcribed Spacer Region Amplification, Cloning and Sanger Sequencing}

We targeted fungal ITS regions for PCR amplification as previously described [Green et al. 2016]. Briefly, fungal ITS region sequences were amplified with the primer pair Fun18Sf (TTGCTCTTCAACGAGGAAT) and ITS4 (TCCTCCGCTTATTGATATGC). The fungal ITS1 and ITS2 regions were amplified with Platinum Taq DNA polymerase (Invitrogen) according to the methods previously described [Green et al. 2016]. Three replicate PCR 
reactions $(50 \mu \mathrm{L})$ were run for each sample by using $5 \mu \mathrm{L}$ of DNA template. These replicates were then combined, and the ribosomal deoxyribonucleic acid amplicons were purified with a Qiagen PCR purification kit, according to the manufacturer's instructions. We ran the purified product $(8 \mu \mathrm{L})$ on a $1 \%$ agarose gel that contained 1 microgram per $\mathrm{mL}$ ethidium bromide and examined for amplicons with ultraviolet light.

We cloned fungal amplicons into the pDRIVE vector using a Qiagen PCR cloning kit. We generated clone libraries by transforming cloned plasmids into chemically competent Escherichia coli cells as previously described [Green et al. 2016]. We selected positive colonies (as determined colorimetrically by the inactivation of the lacZ gene) and cultured for 16 hours at $37^{\circ} \mathrm{C}$ in liquid Luria-Bertani media that contained 100 microgram per $\mathrm{mL}$ of ampicillin. Resultant cells were centrifuged at $1800 \times \mathrm{g}$ (relative centrifugal force) and the pellet resuspended in $200 \mu \mathrm{L}$ of $15 \%$ glycerol, and sent for Sanger sequencing of the fungal ITS insert from Genewiz, Inc. Inserts were sequenced in both directions, allowing for sequence analysis of the full ITS region.

Sequencing results were downloaded as ".ab1" chromatogram files from Genewiz Inc. Vector sequence data were trimmed, and forward and reverse sequences were assembled with Biomatters Geneious R7 Software. Then we sequenced the DNA to identify which varieties of fungi were present in the air. Sequence data were then clustered into operational taxonomic units with MOTHUR software version 1.32.1 using a 97\% similarity cutoff as described in previous publications [Green et al. 2016]. Sequences representative of each operational taxonomic unit were then used in a Basic Local Alignment Search Tool search against the National Center for Biotechnology Information database. 


\section{Appendix D: Occupational Exposure Limits and Health Effects}

NIOSH investigators refer to mandatory (legally enforceable) and recommended OELs for chemical, physical, and biological agents when evaluating workplace hazards. OELs have been developed by federal agencies and safety and health organizations to prevent adverse health effects from workplace exposures. Generally, OELs suggest levels of exposure that most employees may be exposed to for up to 10 hours per day, 40 hours per week, for a working lifetime, without experiencing adverse health effects. However, not all employees will be protected if their exposures are maintained below these levels. Some may have adverse health effects because of individual susceptibility, a pre-existing medical condition, or a hypersensitivity (allergy). In addition, some hazardous substances act in combination with other exposures, with the general environment, or with medications or personal habits of the employee to produce adverse health effects. Most OELs address airborne exposures, but some substances can be absorbed directly through the skin and mucous membranes.

Most OELs are expressed as a TWA exposure. A TWA refers to the average exposure during a normal 8- to 10-hour workday. Some chemical substances and physical agents have recommended STEL or ceiling values. Unless otherwise noted, the STEL is a 15-minute TWA exposure. It should not be exceeded at any time during a workday. The ceiling limit should not be exceeded at any time.

In the United States, OELs have been established by federal agencies, professional organizations, state and local governments, and other entities. Some OELs are legally enforceable limits; others are recommendations.

- The U.S. Department of Labor OSHA PELs (29 CFR 1910 [general industry]; 29 CFR 1926 [construction industry]; and 29 CFR 1917 [maritime industry]) are legal limits. These limits are enforceable in workplaces covered under the Occupational Safety and Health Act of 1970.

- NIOSH RELs are recommendations based on a critical review of the scientific and technical information and the adequacy of methods to identify and control the hazard. NIOSH RELs are published in the NIOSH Pocket Guide to Chemical Hazards [NIOSH 2010]. NIOSH also recommends risk management practices (e.g., engineering controls, safe work practices, employee education/training, PPE, and exposure and medical monitoring) to minimize the risk of exposure and adverse health effects.

- Another set of OELs commonly used and cited in the United States are ACGIH TLVs. The TLVs are developed by committee members of this professional organization from a review of the published, peer-reviewed literature. TLVs are not consensus standards. They are considered voluntary exposure guidelines for use by industrial hygienists and others trained in this discipline "to assist in the control of health hazards" [ACGIH 2018].

Outside the United States, OELs have been established by various agencies and organizations and include legal and recommended limits. The Institut für Arbeitsschutz der Deutschen Gesetzlichen Unfallversicherung (Institute for Occupational Safety and Health of the German 
Social Accident Insurance) maintains a database of international OELs from European Union member states, Canada (Québec), Japan, Switzerland, and the United States. The database, available at http://www.dguv.de/ifa/GESTIS/GESTIS-Internationale-Grenzwerte-fürchemische-Substanzen-limit-values-for-chemical-agents/index-2.jsp, contains international limits for more than 2,000 hazardous substances and is updated periodically.

OSHA requires an employer to furnish employees a place of employment free from recognized hazards that cause or are likely to cause death or serious physical harm [Occupational Safety and Health Act of 1970 (Public Law 91-596, sec. 5(a)(1))]. This is true in the absence of a specific OEL. It also is important to keep in mind that OELs may not reflect current health-based information.

When multiple OELs exist for a substance or agent, NIOSH investigators generally encourage employers to use the lowest OEL when making risk assessment and risk management decisions. NIOSH investigators also encourage use of the hierarchy of controls approach to eliminate or minimize workplace hazards. This includes, in order of preference, the use of (1) substitution or elimination of the hazardous agent, (2) engineering controls (e.g., local exhaust ventilation, process enclosure, dilution ventilation), (3) administrative controls (e.g., limiting time of exposure, employee training, work practice changes, medical surveillance), and (4) PPE (e.g., respiratory protection, gloves, eye protection, hearing protection). Control banding, a qualitative risk assessment and risk management tool, is a complementary approach to protecting employee health. Control banding focuses on how broad categories of risk should be managed. Information on control banding is available at http://www.cdc.gov/niosh/topics/ctrlbanding/. This approach can be applied in situations where OELs have not been established or can be used to supplement existing OELs.

\section{Endotoxins}

Endotoxins are found throughout the agricultural environment. Endotoxins are found in the cell wall of Gram-negative bacteria and are released when the bacterial cell is lysed (broken down) or when it is multiplying. In experimental studies, human volunteers exposed via inhalation to high levels of endotoxin experience airway and alveolar inflammation as well as chest tightness, fever, and malaise, and have an acute reduction in lung function, as measured by the forced expiratory volume in one second [Castellan 1995]. Airborne endotoxin exposures between 45 and $400 \mathrm{EU} / \mathrm{m}^{3}$ have been associated with acute airflow obstruction, mucous membrane irritation, chest tightness, cough, shortness of breath, fever, and wheezing [Thorne and Duchaine 2007]. Chronic health effects that have been associated with airborne endotoxin exposures include asthma, chronic bronchitis, bronchial hyperreactivity, chronic airway obstruction, hypersensitivity pneumonitis, and organic dust toxic syndrome [Duquenne et al. 2013; Rylander 2006]. Some studies suggest that high environmental and occupational endotoxin exposures may protect exposed individuals from developing atopic sensitization [Rylander 2006].

Rylander and Jacobs have suggested an occupational threshold concentration for endotoxin equivalent to $100 \mathrm{EU} / \mathrm{m}^{3}$ of air to prevent airway inflammation [Rylander and Jacobs 1997]. 
No accepted OELs have been developed in the United States because of the variability of sampling and analytical methods, and because of a lack of data showing a consistent doseresponse relationship [AIHA 2005; Duquenne et al. 2013]. In 2010, DECOS recommended a health-based OEL for airborne endotoxin of $90 \mathrm{EU} / \mathrm{m}^{3}$ as an 8-hour TWA [DECOS 2010].

\section{$\Delta$ 9-THC}

$\triangle 9$-THC is the psychoactive component of cannabis. The health effects from an effective dose of cannabis may include mood changes, diminished memory, and disorientation [NIDA 2016]. Health effects from long-term occupational exposures are unknown, in part because occupational exposures to $\triangle 9$-THC are thought to be predominantly through skin absorption and ingestion. Past $\triangle 9$-THC and health effects research has focused primarily on inhalation in nonoccupational settings.

The adverse health effects associated with nonmedicinal and chronic consumption of $\triangle 9-\mathrm{THC}$ derived from Cannabis sativa and Cannabis indica have been extensively studied and reviewed [Hall and Degenhardt 2014; Volkow et al. 2014]. In contrast, the short-term and long-term health effects of occupational exposure to Cannabis spp. material are not well described in the literature. In addition to $\triangle 9$-THC and cannabinol, cannabis production employees may be exposed to a variety of plant-derived materials such as leaves, buds, sap/exudate, flowers, and pollen when handling the plant during cultivation and processing procedures. They can also encounter other contaminant and plant pathogen sources such as bacteria and fungi. These secondary exposures may result in occupational byssinosis, a lung disease associated with textile fibers (cotton, hemp, etc.) [Valic et al. 1968; Zuskin et al. 1990].

\section{Hemp}

Hemp, also derived from Cannabis sativa, is used for a variety of purposes including fiber, rope, paper composites, food, and oil and oil-based products [USDA 2000]. Occupational hemp exposure can result in a variety of clinical symptoms including sinusitis, byssinosis, and reductions in lung function [Zuskin et al. 1990, 1992, 1994]. Employees who directly handle the plant are particularly at risk [Barbero and Flores 1967; Valic et al. 1968; Zuskin et al. 1990, 1994]. Transdermal applications of medicinal cannabis demonstrate that occupational dermal absorption is a potential exposure route [Goldsmith et al. 2015]. Other studies have also demonstrated dermal reactions such as an urticarial rash (hives) in subjects who directly contact cannabis [Basharat et al. 2011; Ozyurt et al. 2014]. Urticaria has also occurred in forensic specialists and law enforcement officers following the handling of cannabis [Herzinger et al. 2011; Majmudar et al. 2006; Mayoral et al. 2008; Williams et al. 2008]. Several of these plant components have recently been shown to produce high molecular weight proteins that can result in the allergic sensitization following personal exposure [Nayak et al. 2013]. 


\section{References}

Abrams DI [2018]. The therapeutic effects of cannabis and cannabinoids: an update from the National Academies of Sciences, Engineering and Medicine report. Eur J Intern Med Epub ahead of print, https://doi.org/10.1016/j.ejim.2018.01.003.

ACGIH [2018]. 2018 TLVs ${ }^{\circledR}$ and BEIs ${ }^{\circledR}$ : threshold limit values for chemical substances and physical agents and biological exposure indices. Cincinnati, $\mathrm{OH}$ : American Conference of Governmental Industrial Hygienists.

AIHA [2005]. Field guide for the determination of biological contaminants in environmental samples. 2nd edition. Falls Church, Virginia: American Industrial Hygiene Association.

Ambach L, Penitschka F, Broillet A, Konig S, Weinmann W, Bernhard W [2014]. Simultaneous quantification of delta-9-THC, THC-acid A, CBN, and CBD in seized drugs using HPLC-DAD. Forensic Sci Int 243(Suppl C):107-111, https://doi.org/10.1016/j.forsciint.2014.06.008.

Ampere A, Delhaes L, Soots J, Bart F, Wallaert B [2012]. Hypersensitivity pneumonitis induced by Shiitake mushroom spores. Medical mycology 50(6):654-657, https://doi.org/10.3109/13693786.2012.658091.

Anderson S, Franko J, Jackson L, Wells J, Ham J, Meade B [2012]. Irritancy and allergic responses induced by exposure to an indoor air chemical 4-Oxopentanal. Toxicological Sciences 127(2):371-381, https://doi.org/10.1093/toxsci/kfs102.

Barbero A, Flores R [1967]. Dust disease in hemp workers. Arch Environ Health 14(4):529-532.

Basharat P, Sussman G, Beezhold D, Leader N [2011]. Hypersensitivity reactions to marijuana. J Allergy Clin Immunol 127(2):AB178, http://dx.doi.org/10.1016/j.jaci.2010.12.707.

Bekci TT, Calik M, Calik SG, Esme H [2014]. Oyster mushrooms (pleurotus ostreatus) caused hypersensitivity pneumonitis: mushroom worker's lung. Eur Respir J 44(Suppl 58):P4023.

Burney P, Chinn S [1987]. Developing a new questionnaire for measuring the prevalence and distribution of asthma. Chest 91(Suppl 6):79S-83S.

Burney PG, Laitinen LA, Perdrizet S, Huckauf H, Tattersfield AE, Chinn S, Poisson N, Heeren A, Britton JR, Jones T [1989]. Validity and repeatability of the IUATLD (1984) bronchial symptoms questionnaire: an international comparison. Eur Respir J 2(10):940-945.

Burney PG, Luczynska C, Chinn S, Jarvis D [1994]. The European community respiratory health survey. Eur Respir J 7(5):945-960.

Cambrex [2005]. Limulus Amebocyte Lysate (LAL), Kinetic-QCL. Catalog Number: 50-650U. Walkersville, MD.

Castellan RM [1995]. Respiratory health effects of inhaled endotoxins: byssinosis and beyond. In: McDuffie H, Dosman J, Semchuk K, Olenchock S, eds. Agricultural health and safety—workplace, environment, sustainability. Boca Raton, FL: CRC Press, pp. 97-100. 
CDC (Centers for Disease Control and Prevention) [1996]. Third National Health and Nutrition Examination Survey, 1988-1994, NHANES III Examination Data File [CDROM] Hyattsville, Maryland: U.S. Department of Health and Human Services, Centers for Disease Control and Prevention (Public use data file documentation No. 76300).

CDPHE [2017]. Guide to worker safety and health in the marijuana industry. Denver, Colorado: Marijuana Occupational Health and Safety Work Group, Colorado Department of Public Health and Environment (CDPHE), https://www.colorado.gov/pacific/cdphe/marijuana-occupational-safety-and-health.

CFR. Code of Federal Regulations. Washington, DC: U.S. Government Printing Office, Office of the Federal Register.

Clark MW, Warren BA, Hagen PT, Johnson BD, Jenkins SM, Werneburg BL, Olsen KD [2011]. Stress level, health behaviors, and quality of life in employees joining a wellness center. Am J Health Promot 26(1):257-285, http://dx.doi.org/10.4278/ajhp.090821-QUAN-272.

DECOS [2010]. Endotoxins: health-based recommended occupational exposure limit. The Hague, Netherlands: Health Council of The Netherlands, Dutch Expert Committee on Occupational Standards, https:/www.gezondheidsraad.nl/sites/default/files/201004OSH.pdf.

Duquenne P, Marchand G, Duchaine C [2013]. Measurement of endotoxins in bioaerosols at workplace: a critical review of literature and a standardization issue. Ann Occup Hyg 57(2):137-172, http://dx.doi.org/10.1093/annhyg/mes051.

Dutkiewicz J, Krysińska-Traczyk E, Skórska C, Sitkowska J, Prazmo Z, Golec M [2001]. Exposure to airborne microorganisms and endotoxin in herb processing plants. Ann Agric Environ Med 8(2):201-211.

ECRHS (European Community Respiratory Health Survey) [2014]. Questionnaires, protocols and instructions, http://www.ecrhs.org/quests.htm.

Ferris BG [1978]. Epidemiology standardization project. Am Rev Respir Dis 118(Suppl):1-53.

Fishwick D, Allan LJ, Wright A, Curran AD [2001]. Assessment of exposure to organic dust in a hemp processing plant. Ann Occup Hyg 45(7):577-583, http://dx.doi.org/10.1093/annhyg/45.7.577.

Gardes M, Bruns TD [1993]. ITS primers with enhanced specificity for basidiomycetesapplication to the identification of mycorrhizae and rusts. Mol Ecol 2(2):113-118.

Goldsmith RS, Targino MC, Fanciullo GJ, Martin DW, Hartenbaum NP, White JM, Franklin $\mathrm{P}$ [2015]. Medical marijuana in the workplace: challenges and management options for occupational physicians. J Occup Environ Med 57(5):518-525, http://dx.doi.org/10.1097/JOM.0000000000000454.

Green BJ, Lemons AR, Park Y, Cox-Ganser JM, Park JH [2016]. Assessment of fungal diversity in a water-damaged office building. J Occupational Environ Hyg 14(4):285-293, https://doi.org/10.1080/15459624.2016.1252044. 
Hall W, Degenhardt L [2014]. The adverse health effects of chronic cannabis use. Drug Test Anal 6(1-2):39-45, http://dx.doi.org/10.1002/dta.1506.

Hankinson JL, Odencrantz JR, Fedan KB [1999]. Spirometric reference values from a sample of the general U.S. population. Am J Respir Crit Care Med 159(1):179-187, https://doi.org/10.1164/ajrccm.159.1.9712108.

Herzinger T, Schopf P, Przybilla B, Rueff F [2011]. IgE-mediated hypersensitivity reactions to cannabis in laboratory personnel. Int Arch Allergy Immunol 156(4):423-426, http://dx.doi.org/10.1159/000324444.

Hibbett DS, Bauer R, Binder M, Giachini AJ, Hosaka K, Justo A, Larsson E, Larsson KH, Lawrey JD, Miettinen O, Nagy LG, Nilsson RH, Weiss M, Thorn RG [2014]. Agaricomycetes. In: McLaughlin JD, Spatafora WJ (eds). Systematics and Evolution: Part A. Springer Berlin Heidelberg, Berlin, Heidelberg, pp 373-429.

Hodgson MJ, Flannigan B [2017]. Occupational respiratory disease: hypersensitivity pneumonitis and other forms of interstitial lung disease. In: Flannigan B, Samson R, Miller J, eds. Microorganisms in Home and Indoor Work Environments: Diversity, Health Impacts, Investigation and Control. 2nd ed. Boca Raton, FL: CRC Press, Taylor \& Francis Group.

Jackson SR, Ham JE, Harrison JC, Wells JR [2016]. Identification and quantification of carbonyl-containing alpha-pinene ozonolysis products using O-tert-butylhydroxylamine hydrochloride. J Atmos Chem 74(3):325-338, https://dx.doi.org/10.1007\%2Fs10874-016-9344-6.

Jarvis J, Seed MJ, Elton R, Sawyer L, Agius R [2005]. Relationship between chemical structure and the occupational asthma hazard of low molecular weight organic compounds. Occ Environ Med 62:243-250, http://dx.doi.org/10.1136/oem.2004.016402.

Lappalainen S, Pasanen A-L, Reiman M, Kalliokoski P [1998]. Serum IgG Antibodies Against Wallemia sebi and Fusarium Species in Finnish Farmers. Ann Allergy Asthma Immunol 81(6):585-592, https://doi.org/10.1016/S1081-1206(10)62710-X.

LeBouf RF, Stefaniak AB, Virji MA [2012]. Validation of evacuated canisters for sampling volatile organic compounds in healthcare settings. J Environ Monit 14(3):977-983, https://dx.doi.org/10.1039/c2em10896h.

LeBouf RF, Simmons M [2017]. Increased sensitivity of OSHA method analysis of diacetyl and 2,3-pentanedione in air. J Occup Environ Hyg 14(5):343-348, http://dx.doi.org/10.1080/15459624.2016.1252846.

Majmudar V, Azam NA, Finch T [2006]. Contact urticaria to cannabis sativa. Contact Dermatitis 54(2):127, http://dx.doi.org/10.1111/j.0105-1873.2006.0560h.x.

Mayoral M, Calderon H, Cano R, Lombardero M [2008]. Allergic rhinoconjunctivitis caused by cannabis sativa pollen. J Investig Allergol Clin Immunol 18(1):73-74. 
Miller MR, Hankinson J, Brusasco V, Burgos F, Casaburi R, Coates A, Crapo R, Enright P, van der Grinten CP, Gustafsson P, Jensen R, Johnson DC, MacIntryre N, McKay R, Navajas D, Pedersen OF, Morey PR, Horner E, Epstien BL, Worthan AG, Black MS [2010]. Indoor air quality in nonindustrial occupational environments. In: Rose VE, Cohrssen B, eds. Patty's industrial hygiene. 6th ed. 4 vol. New York: John Wiley \& Sons, Inc.

Morey PR [2001]. Microbiological investigations in indoor environments: interpreting sampling data-selected case studies. In: Flannigan B, Samson R, Miller J, eds.

Microorganisms in Home and Indoor Work Environments: Diversity, Health Impacts, Investigation and Control. 2nd ed. Boca Raton, FL: CRC Press, Taylor \& Francis Group.

Nayak AP, Green BJ, Sussman G, Berlin N, Lata H, Chandra S, ElSohly MA, Hettick JM, Beezhold DH [2013]. Characterization of cannabis sativa allergens. Ann Allergy Asthma Immunol 111:32-37e4, http://dx.doi.org/10.1016/j.anai.2013.04.018.

NCHS (National Center for Health Statistics) [2015]. National Health and Nutrition Examination Survey (NHANES). Hyattsville, Maryland: U.S. Department of Health and Human Services, Centers for Disease Control and Prevention, http://www.cdc.gov/nchs/nhanes/about_nhanes.htm.

NIDA [2016]. DrugFacts: marijuana. Rockville, MD: U.S. Department of Health and Human Services, National Institutes of Health, National Institute on Drug Abuse, https:/www.drugabuse.gov/publications/drugfacts/marijuana.

NIOSH [2010]. NIOSH pocket guide to chemical hazards. Cincinnati, OH: U.S. Department of Health and Human Services, Centers for Disease Control and Prevention, National Institute for Occupational Safety and Health, DHHS (NIOSH) Publication No. 2010-168c, http://www.cdc.gov/niosh/npg/.

NIOSH [2016]. Criteria for a recommended standard: occupational exposure to diacetyl and 2,3-pentanedione. By McKernan LT, Niemeier RT, Kreiss K, Hubbs A, Park R, Dankovic D, Dunn KH, Parker J, Fedan K, Streicher R, Fedan J, Garcia A, Whittaker C, Gilbert S, Nourian F, Galloway E, Smith R, Lentz TJ, Hirst D, Topmiller J, Curwin B. Cincinnati, OH: U.S. Department of Health and Human Services, Centers for Disease Control and Prevention, National Institute for Occupational Safety and Health, DHHS (NIOSH) Publication No. 2016-111, https:/www.cdc.gov/niosh/docs/2016-111/pdfs/2016-111-all.pdf.

NIOSH [2017]. Evaluation of potential hazards during harvesting and processing cannabis at an outdoor organic farm. By Couch J, Victory K, Lowe B, Burton N, Green B, Nayak A, Lemons A, Beezhold D. Cincinnati, OH: U.S. Department of Health and Human Services, Centers for Disease Control and Prevention, National Institute for Occupational Safety and Health, Health Hazard Evaluation Report 2015-0111-3271, http://www.cdc.gov/niosh/hhe/reports/pdfs/2015-0111-3271.pdf.

NIOSH [2018]. NIOSH manual of analytical methods (NMAM). 5th ed. O'Connor PF, Ashley K, eds. Cincinnati, OH: U.S. Department of Health and Human Services, Centers for Disease Control and Prevention, National Institute for Occupational Safety and Health, DHHS (NIOSH) Publication No. 2014-151, http://www.cdc.gov/niosh/nmam. 
OSHA [2008]. Sampling and analytical methods: method 1013 - acetoin and diacetyl, http:// www.osha.gov/dts/sltc/methods/validated/1013/1013.html.

OSHA [2010]. Sampling and analytical methods: method 1016 - 2,3-pentanedione, http:// www.osha.gov/dts/sltc/methods/validated/1016/1016.html.

Ozyurt S, Muderrisoglu F, Ermete M, Afsar F [2014]. Cannabis-induced erythema multiforme-like recurrent drug eruption. Int J Dermatol 53(1):e22-e23, http://dx.doi.org/10.1111/j.1365-4632.2011.05318.x.

Pelligrino R, Viegi G, Wagner J, ATS/ERS Task Force [2005a]. Standardisation of spirometry. Eur Respir J 26(2):319-338.

Pelligrino R, Viegi G, Brusasco V, Crapo RO, Burgos F, Casaburi R, Coates A, can der Grinten CP, Gustafsson P, Hankinson J, Jensen R, Johnson DC, MacIntyre N, McKay R, Miller MR, Navajas D, Pdersen OF, Wagner J [2005b]. Interpretative strategies for lung function tests. Eur Respir J 26(5):948-968, https://dx.doi.org/10.1183/09031936.05.00035205.

Pitkäranta M, Meklin T, Hyvärinen A, Nevalainen A, Paulin L, Auvinen P, Lignell U, Rintala $\mathrm{H}$ [2011]. Molecular profiling of fungal communities in moisture damaged buildings before and after remediation-a comparison of culture-dependent and culture-independent methods. BMC Microbiology 11:235, https://dx.doi.org/10.1186/1471-2180-11-235.

Rittenour WR, Ciaccio CE, Barnes CS, Kashon ML, Lemons AR, Beezhold DH, Green BJ [2014]. Internal transcribed spacer rRNA gene sequencing analysis of fungal diversity in Kansas City indoor environments. Environ Sci Process Impacts 16(1):33-43, https://dx.doi.org/10.1039/c3em00441d.

Rylander R, Jacobs RR [1997]. Endotoxin in the environment. Int J Occup Environ Health 3(1):S1-S31.

Rylander R [2006]. Endotoxin and occupational airway disease. Curr Opin Allergy Clin Immunol 6(1):62-66, http://dx.doi.org/10.1097/01.all.0000202356.83509.f7.

Singer BC, Destaillats H, Hodgson AT, Nazaroff WW [2006]. Cleaning products and air fresheners: emissions and resulting concentrations of glycol ethers and terpenoids. Indoor Air 16(3):179-191, https://dx.doi.org/10.1111/j.1600-0668.2005.00414.x.

Skórska C, Sitkowska J, Krysińska-Traczyk E, Cholewa G, Dutkiewicz J [2005]. Exposure to airborne microorganisms, dust and endotoxin during processing of peppermint and chamomile herbs on farms. Ann Agric Environ Med 12(2):281-288.

Thilsing T, Madsen AM, Basinas I, Schlünssen V, Tendal K, Bælum J [2015]. Dust, endotoxin, fungi, and bacteria exposure as determined by work task, season, and type of plant in a flower greenhouse. Ann Occup Hyg 59(2):142-157, http://dx.doi.org/10.1093/annhyg/meu090.

Thorne PS, Duchaine C [2007]. Airborne bacteria and endotoxin. In: Hurst CJ, Crawford RL, Garland JL, Lipson DA, Mills AL, Stetzenbach LD, eds. Manual of environmental microbiology. 3rd ed. Washington, DC: American Society for Microbiology Press, pp. 989-1004. 
Trout DB, Seltzer JM, Page EH, Biagini RE, Schmechel D, Lewis DM, Boudreau AY [2004]. Clinical use of immunoassays in assessing exposure to fungi and potential health effects related to fungal exposure. Ann Allergy Asthma Immunol 92(5):483-492, http://dx.doi.org/10.1016/S1081-1206(10)61754-1.

USDA [2000]. Industrial hemp in the United States: status and market potential. United States Drug Administration, Economic Research Service, http://www.ers.usda.gov/media/328262/ages001e 1 .pdf.

Valic F, Zuskin E, Walford J, Kersic W, Paukovic R [1968]. Bysinnosis, chronic bronchitis and ventilatory capacities in workers exposed to soft hemp dust. Br J Ind Med 25(3):176-186.

Volkow ND, Baler RD, Compton WM, Weiss SR [2014]. Adverse health effects of marijuana use. N Engl J Med 370:2219-2227, http://dx.doi.org/10.1056/NEJMra1402309.

Weel ANH, Fortuin RJ [1998]. Design and trial of a new questionnaire for occupational health surveys in companies. Occup Med 48(8):511-518, https://dx.doi.org/10.1093/ occmed/48.8.511.

Weschler CJ [2000]. Ozone in indoor environments: concentration and chemistry. Indoor Air 10(4):269-288, https://dx.doi.org/10.1034/j.1600-0668.2000.010004269.x.

Williams C, Thompstone J, Wilkinson M [2008]. Work-related contact urticaria to cannabis sativa. Contact Dermatitis 58(1):62-63, http://dx.doi.org/10.1111/j.1600-0536.2007.01169.x.

Yamamoto N, Nazaroff WW, Peccia J [2014]. Assessing the aerodynamic diameters of taxon-specific fungal bioaerosols by quantitative PCR and next-generation DNA sequencing. J Aerosol Sci 78:1-10, https://doi.org/10.1016/j.jaerosci.2014.08.007.

Zuskin E, Kanceljak B, Pokrajac D, Schachter EN, Witek Jr. TJ [1990]. Respiratory symptoms and lung function in hemp workers. Br J Ind Med 47(9):627-632.

Zuskin E, Kanceljak B, Schachter EN, Witek Jr. TJ, Maayani S, Goswami S, Marom Z, Rienzi N [1992]. Immunological findings in hemp workers. Env Res 59(2):350-361.

Zuskin E, Mustajbegovic J, Schachter EN [1994]. Follow-up study of respiratory function in hemp workers. Am J Ind Med 26(1):103-115. 
Keywords: North American Industry Classification System (NAICS) 111419 (Marijuana, Grown Under Cover), Minnesota, Cannabis, Agriculture, VOC, Fungus, Pulmonary Function Tests, PFTs, Job Stress 
This page left intentionally blank 
The Health Hazard Evaluation Program investigates possible health hazards in the workplace under the authority of the Occupational Safety and Health Act of 1970 (29 U.S.C. § 669(a) (6)). The Health Hazard Evaluation Program also provides, upon request, technical assistance to federal, state, and local agencies to investigate occupational health hazards and to prevent occupational disease or injury. Regulations guiding the Program can be found in Title 42, Code of Federal Regulations, Part 85; Requests for Health Hazard Evaluations (42 CFR Part 85).

\section{Disclaimer}

The recommendations in this report are made on the basis of the findings at the workplace evaluated and may not be applicable to other workplaces.

Mention of any company or product in this report does not constitute endorsement by NIOSH.

Citations to Web sites external to NIOSH do not constitute NIOSH endorsement of the sponsoring organizations or their programs or products. NIOSH is not responsible for the content of these Web sites. All Web addresses referenced in this document were accessible as of the publication date.

\section{Acknowledgments}

Analytical Support: Ryan LeBouf, Jennifer Roberts, Charles Mueller, Maxxam Analytics Desktop Publisher: Shawna Watts

Editor: Ellen Galloway

Industrial Hygiene Field Assistance: Bradley King

Logistics: Donnie Booher, Kevin Moore

Medical Field Assistance: Chrissy Toennis, Victoria Hall

Survey Methods Assistance: Charles Mueller, Reid Harvey, Ethan Fechter-Leggett

\section{Availability of Report}

Copies of this report have been sent to the employer, employees, and union at the facility. The state and local health department and the Occupational Safety and Health Administration Regional Office have also received a copy. This report is not copyrighted and may be freely reproduced.

\section{Recommended citation for this report:}

NIOSH [2018]. Evaluation of a medicinal cannabis manufacturing facility with an indoor and outdoor grow operation. By Couch J, Wiegand D, Grimes GR, Green BJ, Lemons AR, Glassford E, Zwack L, Jackson SR, Beezhold D. Cincinnati, OH: U.S. Department of Health and Human Services, Centers for Disease Control and Prevention, National Institute for Occupational Safety and Health, Health Hazard Evaluation Report 20160090-3317, https://www.cdc.gov/niosh/hhe/reports/pdfs/2016-0090-3317.pdf. 
Delivering on the Nation's promise:

Promoting productive workplaces through safety and health research

To receive NIOSH documents or more information about occupational safety and health topics, please contact NIOSH:

Telephone: 1-800-CDC-INFO (1-800-232-4636)

TTY: 1-888-232-6348

CDC INFO: www.cdc.gov/info

or visit the NIOSH Web site at www.cdc.gov/niosh

For a monthly update on news at $\mathrm{NIOSH}$, subscribe to

$\mathrm{NIOSH}$ eNews by visiting www.cdc.gov/niosh/eNews. 